OPEN ACCESS

Edited by:

Marco Rinaldo Oggioni,

University of Leicester,

United Kingdom

Reviewed by:

Sunil Joshi,

University of Miami, United States

Jiezuan Yang,

Zhejiang University, China

Marielle C. Haks,

Leiden University Medical Center,

Netherlands

Yean Kong Yong,

Xiamen University, Malaysia

${ }^{*}$ Correspondence:

Pawan Gupta

pawan@imtech.res.in

Specialty section: This article was submitted to

Microbial Immunology,

a section of the journal

Frontiers in Immunology

Received: 29 January 2020

Accepted: 07 August 2020

Published: 15 October 2020

Citation:

Gupta S and Gupta P (2020) Etiopathogenesis, Challenges and

Remedies Associated With Female Genital Tuberculosis: Potential Role of Nuclear Receptors.

Front. Immunol. 11:02161. doi: 10.3389/fimmu.2020.02161

\section{Etiopathogenesis, Challenges and Remedies Associated With Female Genital Tuberculosis: Potential Role of Nuclear Receptors}

\author{
Shalini Gupta and Pawan Gupta* \\ Department of Molecular Biology, CSIR-Institute of Microbial Technology, Chandigarh, India
}

Extra-pulmonary tuberculosis (EPTB) is recognized mainly as a secondary manifestation of a primary tuberculosis (TB) infection in the lungs contributing to a high incidence of morbidity and mortality. The TB bacilli upon reactivation maneuver from the primary site disseminating to other organs. Diagnosis and treatment of EPTB remains challenging due to the abstruse positioning of the infected organs and the associated invasiveness of sample acquisition as well as misdiagnosis, associated comorbidities, and the inadequacy of biomarkers. Female genital tuberculosis (FGTB) represents the most perilous form of EPTB leading to poor uterine receptivity (UR), recurrent implantation failure and infertility in females. Although the number of TB cases is reducing, FGTB cases are not getting enough attention because of a lack of clinical awareness, nonspecific symptoms, and inappropriate diagnostic measures. This review provides an overview for EPTB, particularly FGTB diagnostics and treatment challenges. We emphasize the need for new therapeutics and highlight the need for the exaction of biomarkers as a point of care diagnostic. Nuclear receptors have reported role in maintaining UR, immune modulation, and TB modulation; therefore, we postulate their role as a therapeutic drug target and biomarker that should be explored in FGTB.

Keywords: nuclear receptors, uterine receptivity, cytokine modulation, female genital tuberculosis, recurrent implantation failure, endometrium regeneration, extrapulmonary tuberculosis

\section{INTRODUCTION}

Mycobacterium tuberculosis (M. tuberculosis) is an etiological agent that causes tuberculosis (TB), which is a health issue of global importance. TB profoundly exists in two forms, i.e., pulmonary and extrapulmonary. The most prevalent site of TB infection is the lungs; this is called pulmonary TB (PTB), where the bacilli are phagocytosed in alveolar macrophages and are contagious via

\footnotetext{
Abbreviations: EPTB, Extrapulmonary Tuberculosis; PTB, Pulmonary Tuberculosis; TB, Tuberculosis; FGTB, Female Genital Tuberculosis; RIF, Recurrent Implantation Failure; UR, Uterine Receptivity; ER, Endometrium regeneration; CM, Cytokine modulation; LIF, Leukemia inhibitory factor; VEGF, Vascular endothelial growth factor; NR, Nuclear Receptors; TR4, Testicular receptor; PPAR, Peroxisome Proliferator Activated Receptor; PXR, Pregnane X Receptor; VDR, Vitamin D Receptor; LXR, Liver X Receptor; PR, Progesterone receptor; LRH1, Liver receptor homolog 1; Nurr, Nuclear receptor related; AR, Androgen receptor; COUP-TF, Chicken Ovalbumin Upstream Promoter; SF-1, Steroidogenic Factor; FXR, Farnesoid X Receptor; IL, Interleukin.
} 
aerosol dissemination. TB bacilli can also disseminate to other organs and causes extrapulmonary tuberculosis (EPTB). The genital organs are also an important site for dissemination. Table 1 shows the distribution of TB cases at extrapulmonary sites (1). EPTB is mainly considered to be a secondary manifestation of the primary infection, which is rarely contagious; however, extrapulmonary involvement can occur with or without PTB. The World Health Organization (WHO) reported 7 million TB cases in 2018 of which 15\% were EPTB (2). Additionally, approximately, $10 \%-50 \%$ of EPTB cases are reported to also have pulmonary manifestation (3). The prevalence of EPTB significantly contributes to TB-related morbidity and mortality and is a leading cause of maternal mortality. In a case study, the highest mortality rates are reported for meningitis TB (9.6\%) and peritoneal TB (8.5\%) (4). Peritoneal TB and female genital TB (FGTB) are a threat to human species propagation (5). Bacterial dissemination leading to EPTB occurs majorly via three different channels, i.e., hematogenous, lymphatic, and direct spread (6). Additionally, producing new blood vessels through vascular endothelial growth factor (VEGF) can assist in bacterial dissemination (7). Some rare modes of transmission include congenital transmission, accidental inoculation, therapeutic instillation, and vaccination (8). The atypical presentation, paucibacillary nature, arduousness in procuring appropriate clinical sample, lack of awareness among clinicians, and poor sensitivity of conventional microbiological techniques in EPTB, particularly FGTB, are challenges in diagnosis that further raise the cost due to disability. EPTB cases are on the rise; however, there is still a very extensive awareness gap compared to PTB (15\% vs. $86 \%$ ) (9). The aim of the WHO's "end TB strategy" highlights the need for patient TB care and awareness programs in PTB (10). However, the information on EPTB needs to be adequately addressed. FGTB, which represents the most perilous form of EPTB, is steadily rising as one of the major causes of infertility in females. Globally, about $5 \%-10 \%$ of infertile women are reported to have FGTB (11). FGTB demands immediate attention because of its low recovery rates and the increased abortion rates observed during recent years. Primary infection of TB in the genital tract of females, albeit rare, may occur if the partner has active genitourinary TB. Despite our current understanding, it is vital that research into EPTB and especially FGTB is increased as it is critical to enhance our knowledge of this disease in order to effectively combat it.

TABLE 1 | The bacterial manifestation reported at the surplus site and the prepotency.

\begin{tabular}{lcl}
\hline Extrapulmonary forms & Occupied site of EPTB (\%) & Mode of spread \\
\hline Lymph node TB & $35 \%$ & Direct \\
Pleural TB & $20 \%$ & Hematogenous \\
Meningitis TB & $5 \%$ & Hematogenous \\
Abdomen TB & $3 \%$ & Direct \\
Miliary TB & $8 \%$ & Hematogenous \\
Bone and joint TB & $10 \%$ & Hematogenous \\
Genitourinary TB & $9 \%$ & Hematogenous \\
Others & $10 \%$ &
\end{tabular}

This review highlights the major challenges of EPTB, especially FGTB, and necessitates the need for research efforts for effective biomarker discovery in FGTB. The objective of this review is to introduce the diagnostic, treatment, and comorbidity challenges associated with EPTB and, in particular, FGTB and to raise fundamental biological questions regarding the impact of FGTB on female fertility and on the major issues of endometrium regeneration (ER), uterine receptivity (UR), and cytokine modulation (CM). This review covers the current knowledge of nuclear receptors (NRs), reported in regeneration, female reproduction, and in the maintenance of pregnancy with the aim of conceptually postulating that NRs should be explored in the diagnosis and combating of FGTB-associated female infertility.

\section{EPIDEMIOLOGY AND CLINICAL PRESENTATION OF FGTB: THE SILENT RISE}

FGTB is the most enigmatic form of EPTB, representing 15\%-20\% of EPTB cases $(12,13)$, and is responsible for poor UR, poor endometrial adhesions, and recurrent implantation failure (RIF) in females (14). However, the exact proportion of FGTB is not known due to underreporting of cases, nonspecific symptoms, misleading clinical appearance, and lack of diagnostic measures. Additionally, in a case study, approximately $75.6 \%$ of patients' cases evaluated for infertility were diagnosed with FGTB (15). It is highly concerning because the manifestations are asymptomatic, and by the time FGTB is diagnosed, it has already left an impact on female fertility and morbidity. There is also a social stigma attached to FGTB that causes it to be difficult for women to talk openly about it. FGTB is known to mainly cause primary infertility rather than secondary infertility (16); therefore, even after successful treatment, conception rates are very low (19.2\%), the success of pregnancy is very low $(16.6 \%)$, and the birth rate is also extremely low $(7.2 \%)(17,18)$. The TB bacilli break out from the primary site of infection and reach the genital area generally through hematogenous spread (19). The most prevalent site of bacterial infection for FGTB includes the endometrium (50\%$60 \%)$, fallopian tubes $(95 \%-100 \%)$, ovaries $(20 \%-30 \%)$, cervix (5\%-15\%), myometrium $(2.5 \%)$, and vagina/vulva $(1 \%)(19,20)$. FGTB causes caseation, adhesions, ulcerations, and complete distortion of the cavity causing Asherman syndrome. The clinical appearance of FGTB is generally called "the considerable pretender" because it mimics ovarian carcinoma (21). FGTB represent various clinical symptoms of infertility (43\%-74\%), oligomenorrhea (54\%), amenorrhea (14\%), dysmenorrhea (12\%$30 \%)$, abdominal pain $(42.5 \%)$, menorrhagia (19\%), dyspareunia (5\%-12\%), and postmenopausal bleeding (2\%) $(19,22-25)$. The abovementioned clinical presentations arise because the ER capability is compromised, which contributes to recurrent pregnancy loss and infertility (Table 2). All these symptoms pertain to the endometrium, and its regeneration needs to be addressed and investigated. The key factors that modulate and exacerbate FGTB need to be identified. 
TABLE 2 | Various forms of clinical presentations of FGTB are shown along with signs and symptoms.

\begin{tabular}{|c|c|c|}
\hline $\begin{array}{l}\text { Extrapulmonary } \\
\text { infection }\end{array}$ & $\begin{array}{l}\text { Clinical } \\
\text { presentation }\end{array}$ & Signs and Symptoms \\
\hline TB of endometrium & $\begin{array}{l}\text { Uterine leiomyoma } \\
\text { Postmenopausal } \\
\text { TB } \\
\text { Oligomenorrhoea } \\
\text { Amenorrhoea } \\
\text { Menorrhagia }\end{array}$ & $\begin{array}{l}\text { Pyometra } \\
\text { Irregular vaginal bleeding and } \\
\text { persistent leucorrhoea } \\
\text { Menstrual disturbance } \\
\text { Menstrual disturbance } \\
\text { Abnormal vaginal discharge }\end{array}$ \\
\hline TB of cervix & Ovarian carcinoma & Postcoital bleeding \\
\hline TB of vulva & Tumor & Bloodstained discharge \\
\hline TB of ovary & Perioophoritis & Tubo-ovarian masses \\
\hline TB of fallopian tube & $\begin{array}{l}\text { Salpingitis and } \\
\text { tubal block } \\
\text { Infertility }\end{array}$ & $\begin{array}{l}\text { Ectopic pregnancy } \\
\text { Implantation failure }\end{array}$ \\
\hline TB of pelvic & $\begin{array}{l}\text { Fistula formation } \\
\text { Malaise }\end{array}$ & $\begin{array}{l}\text { Rupture of a tuberculous pyosalpinx } \\
\text { Pelvic inflammatory disease }\end{array}$ \\
\hline
\end{tabular}

\section{THE DIAGNOSTIC CHALLENGES OF EPTB WITH AN EMPHASIS ON FGTB}

The diagnostic tools for ЕРTB include the nucleic acid amplification test (Gene-Xpert), immunological test, biopsy, body fluid examination, and sputum acid-fast bacillus (AFB) smear. Gene-Xpert shows high sensitivity in EPTB samples but is less in cerebrospinal fluid (CSF), i.e., 29\% (26). The antibodybased serological test has poor sensitivity and is not applicable to EPTB samples (27). Blood transcriptomic biomarkers are identified in TB, which can easily discriminate between healthy and infected persons (28-31). The onset of TB can be predicted through metabolite changes in blood (32). Blood transcriptomic and metabolic signatures have improved diagnosis in TB and are being explored as probable diagnosis for ЕРTB $(8,33,34)$. Systematic reviews on TB biomarkers, including antibodies, cytokines, chemokines, proteins, and metabolic activity markers have already been published (35). These biomarkers, to some extent, have also been studied in EPTB $(36,37)$. EPTB is largely undiagnosed in patients, especially when visceral sites are involved. The detection of EPTB, particularly FGTB, poses a major challenge with conventional methods. EPTB diagnosis is challenging because of misdiagnosis, arduousness in acquiring of clinical samples, being asymptomatic, and poor sensitivity of existing diagnostic (Figure 1). Generally, miliary TB is misdiagnosed with systemic lupus erythematosus (SLE) (38). EPTB, particularly peritoneal TB, may also be misinterpreted as ovarian cancer and peritoneal carcinomatosis $(5,39)$. Intestinal TB is misdiagnosed with Crohn disease (40). Bone and joint TB are misdiagnosed as rheumatoid arthritis, traumatism, and gout. Vulva and vaginal TB is misdiagnosed with malignancy (41). Invasiveness and constraints in obtaining biopsies prevent the early diagnosis of EPTB, and in addition, these diagnostic tests can cause incidental damages and infection; for instance, in the case of meningitis TB, extraction of CSF can possibly harm the nerves around the site of insertion. Biopsy, endoscopy, cystoscopy, and lumbar puncture are all performed depending on the case for other EPTBs (8). Meningitis TB is suspected when the patient is diagnosed with mental disturbance or is found to have lymphocytic pleocytosis (42). Due to the nonparticular symptoms, miliary $\mathrm{TB}$ and urogenital $\mathrm{TB}$ are often diagnosed at an autopsy $(8,43-46)$.

Being a paucibacillary disease, the diagnostic measures of FGTB involve a combination of bacteriological confirmatory measures. FGTB patients exhibit features of dysfunction of genital organs rather than any symptoms of infection. Repeatedly invasive techniques are utilized to acquire sufficient samples of body fluids, tissues, or biopsies. FGTB diagnosis is mainly done through endometrial samples using microscopy (AFB), histopathological detection of epithelioid granuloma on biopsy, and Gene-Xpert (41). Peritoneal fluid or biopsy for culture, endoscopy, and cervical cytology are also performed for diagnosis. However, histopathological findings are not specific for FGTB because of shedding of the endometrium. Magnetic resonance imaging and positron emission tomography have been used for detecting tubo-ovarian masses $(47,48)$. Loop-mediated isothermal amplification is the most convenient technique used for diagnosing FGTB (49). A laparoscopy combined with hysteroscopy is the most reliable tool to diagnose FGTB; however, this is associated with perioperative complications. Laparoscopy is risky because of the presence of many adhesions, which cover the pelvic organs and may hinder the diagnosis and can increase the risk of bleeding $(41,50)$. Hysteroscopy is associated with various complications, such as excessive bleeding, perforation, inability to distinguish and distend cavity, and flare-up of genital $\mathrm{TB}$, which can cause abortions and infertility (51). FGTB, specifically endometrial TB, represents ulceration, caseous necrosis, and hemorrhage; this necessitates careful macroscopic sampling $(51,52)$. FGTB is a silent disease; rarely, it presents as abdominal pain, abnormal genital bleeding, and dyspareunia (53). The misdiagnosis rate is very high among FGTB patients and is associated with several complications. The disease is mistaken for other gynecological conditions or malignancy; for example, FGTB is misdiagnosed as ovarian cancer or chocolate cyst or pelvic inflammatory disease (PID) (54), and FGTB patients who are reported to have cervical TB may masquerade as cervical cancer $(41,55)$. Additionally, FGTB patients may be mistaken or coexist with acute appendicitis or ectopic pregnancy (52). TB of the vulva and cervix is very arduous to distinguish as it appears as brucellosis, schistosomiasis, tularemia, cervical amoebiasis, sarcoidosis, syphilis, or chancroid (56). Furthermore, a high level of drug resistance is witnessed in FGTB (57). Given the above challenges with FGTB diagnosis, including exceptional positioning of organs, associated invasiveness of sample collections, misdiagnosis, being asymptomatic, poor sensitivity, the emergence of drug resistance, and the lack of point of care, there is a strong need to identify FGTB-specific biomarkers. The biosignatures emanating from the pathogen have been reported for FGTB diagnosis (58). However, the sensitivity of detection in FGTB patient samples is very low because the infected sites are missed due to the paucibacillary nature of M. tuberculosis. We are focusing on the host-derived biomarkers for the prompt and accurate diagnosis of FGTB from easily accessible samples without utilizing any invasive procedure. 

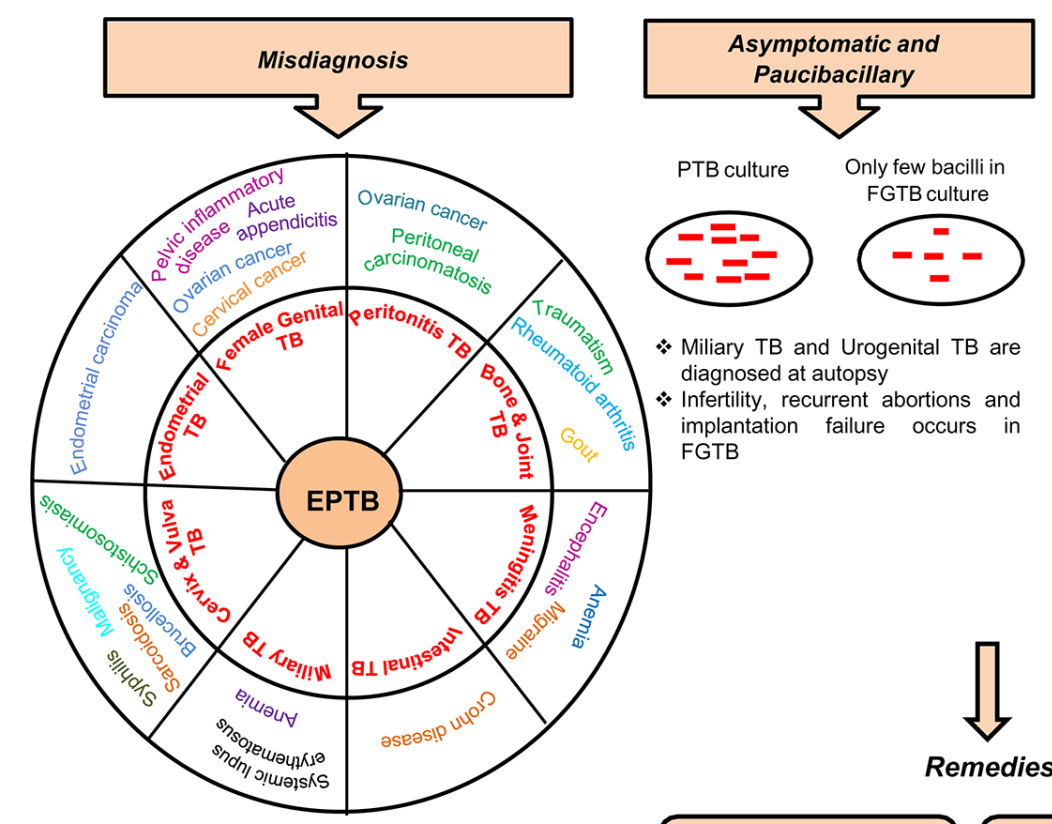

PTB culture

Only few bacilli in FGTB culture

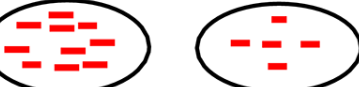

Miliary TB and Urogenital TB are diagnosed at autopsy

imprity, recurrent abortions and FGTB lack of sensitivity of existing conventional methods, and lack of point-of-care diagnostics, lead to loss due to disability.
Lack of sensitivity of

existing diagnostic

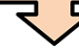

* Gene-Xpert sensitivity varies with the type of specimen

* Antigen based serological test is not applicable

* False positive/ negative

* Sample heterogeneity and varied clinical presentation in FGTB

* Abstruse positioning of organs and impenetrable sites (for ex meningitis TB, endometrial TB, and urogenital TB

* Shedding of the endometrium

- Laparoscopy and Hysteroscopy are

the most reliable tool to diagnose

FGTB, abdino-pelvic TB, Asherman

syndrome, adhesions, however, is

associated with perioperative

complications.

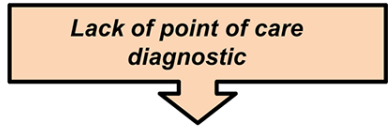

- Inadequacy of biomarkers * Invasiveness associated with sample collection (accessibility issues) - endometrial sampling, CSF collection, pleural and peritoneal fluid, lymph node aspirate, and biopsy

FIGURE 1 | Diagnostic challenges and remedies for EPTB, in particular FGTB. Various challenges associated with EPTB diagnosis, such as misdiagnosis, often asymptomatic and paucibacillary nature of bacilli, 


\section{TREATMENT CHALLENGES OF EPTB WITH AN EMPHASIS ON FGTB}

Treatment of EPTB faces major challenges from comorbidities (e.g., HIV coinfection or renal failure), drug sovereignty, misdiagnosis, drug disposition, and unusual positioning of a few organs, i.e., endometrium, central nervous system (CNS) (Figure 2). Chronic renal failure exacerbates EPTB more than TB (59). During renal impairment, DOTS therapy is eliminated by nonrenal routes; for example, by biliary secretion or through metabolism. Coadministration of anti-HIV and anti-TB drugs in a comorbid condition leads to absorption issues due to a reduction in the assimilation of the two key anti-TB drugs (rifampin and isoniazid) (60). Likewise, TB drugs also lower the levels of antiretroviral drugs; as soon as the antiretroviral therapy is initiated, it paradoxically results in worsening of symptoms or causes immune reconstitution inflammatory syndrome (1, 61). A high proportion of drug-induced liver injuries are observed in cirrhosis patients coinfected with $\mathrm{TB}$ (62). Ascites formed in the body in peritonitis TB present a problem for anti-TB drug disposition (63). Approximately $10 \%-$ $20 \%$ of patients consuming ATT (anti-TB drugs; Ethambutol, Pyrazinamide, Isoniazid, and Rifampicin) either in a single or combinatorial therapy are at a risk of evolving hepatotoxicity (64-66). When EPTB is misdiagnosed as another disease, the treatment for the erroneous disease may exacerbate EPTB; for example, immunosuppressant therapy given when EPTB is misdiagnosed as chronic kidney disease exacerbates the actual case of EPTB $(67,68)$. A case was reported in which immunosuppressant therapy given for SLE in a patient coinfected with disseminated TB led to respiratory failure (69). Meningitis TB treatment is challenging because of the poor penetration of drugs (e.g., rifampin and streptomycin) into the CSF due to the impervious blood-brain barrier (70). EPTB is curable with ATT drugs only to an extent and may result in several complications; for example, patients on ATT treatment may develop acute kidney injuries and increase the risk for nephrotoxicity neuropathy and CNS toxicity (71-73). EPTB treatment also has some exclusion criterion; i.e., chemotherapy is detrimental during the first trimester of pregnancy as it prompts pregnancy termination. Specific adjuvant therapy, chemotherapy, and major surgery are suggested in some uncommon types of EPTB to avoid the complications of TB dissemination (Figure 2). Chemotherapy is required for genitourinary $\mathrm{TB}$ with surgery being substantial and reconstructive surgery required to repair the ureteral strictures (3).

The treatment of FGTB faces formidable challenges from coinfection (HIV, etc.); drug toxicity; obstetric, perioperative, and postoperative complications; reactivation; and emergence of drug-resistant bacteria (Figure 2). FGTB and HIV coinfection make the most deadly combination and is the leading cause of maternal mortality. Moreover, reactivation of bacilli has been observed in FGTB and HIV coinfection (12). HIV-induced immunosuppression in FGTB patients may also cause PID (74). ATT drugs can cause several complications in FGTB (41). Stem cells, nanotechnology, and colostrum are being used as a regenerative therapy to treat damaged endometrium, fallopian tubes, and ovaries (41). Vitamin D plays a crucial role in the treatment of FGTB (75). The use of steroids and immunotherapy is observed to a large extent among infertile patients and leads to resurgence of M. tuberculosis (76). Surgery in FGTB is performed as an adjunctive therapy during persistent or recurrent infection, the presence of nonhealing fistulae, and for multi-drug-resistant TB; however, reactivation of bacilli has been observed during surgery and has been detected after hysterosalpingography, laparoscopy, hysteroscopy, and laparotomy (77). Obstetric complications, such as preterm labor, increased rate of abortions, and neonatal mortality is high in FGTB. Perioperative complications, such as extreme hemorrhage with huge risk of damage to the pelvic and abdominal organs and the bowel, have been discerned during laparotomy (41). FGTB with pervasive adhesions in the uterus and blocked tubes and pelvis is not treatable even after successful treatment (41). Hysteroscopy is used to diagnose the adhesions and Asherman syndrome (78); however, it is associated with several complications in FGTB, such as, inability to visualize the cavity, excessive bleeding, perforation, bowel injury, peritonitis, and flare-up of genital TB $(51,79)$. Postoperative complications, such as bowel fistula and mortality rate are high in FGTB. Repeated invasive measures are required after ATT treatment for proper prognosis for fertility. The conception rate after ATT is only $12.8 \%$, and the outcome of pregnancy could still be a live birth, spontaneous abortion, or ectopic pregnancy $(80,81)$. Furthermore, if patients are considered cured, their chances of pregnancy drop due to the irreversible damage of the fallopian tube and endometrium. Moreover, FGTB, if not properly treated, can cause permanent sterility through endometrial destruction and tubal damage (41). In vitro fertilization (IVF) is considered to be the successful modality for pregnancy in FGTB patients; however, a pregnancy rate of only $17.3 \%$ is observed even after successful treatment $(82,83)$.

The emergence of drug resistance among EPTB, particularly FGTB patients, is on the rise, and it poses a further threat to TB control. EPTB patients have a higher proportion of drug resistance compared to PTB patients (84). Furthermore, a high proportion of drug resistance is witnessed among the treatment failure cases of EPTB (52.7\%) and PTB (48.1\%) (85). The emergence of a multidrug-resistant strain has been reported in FGTB (57). Engineered bacteriophages (Muddy, BPs33 $\Delta$ HTH-HRM10, and ZoeJ $\Delta 45$ ) are used as an adjunctive therapy against drug-resistant disseminated Mycobacterium abscessus (86). Antitubercular peptides, such as cathelicidins, defensins, granulysin, and hepcidin, are developed as novel TB therapeutics against drug-resistant TB (87).

\section{GENITAL TUBERCULOSIS: ADEPTNESS IN IMMUNE MODULATION}

Various molecules that are essential for implantation are being identified as potential players of uterine receptivity, such as growth factors, i.e., VEGF; cytokines, i.e., leukemia inhibitory factor (LIF) (88, 89); and cell adhesion molecules, i.e., CDH1 (E cadherin), 


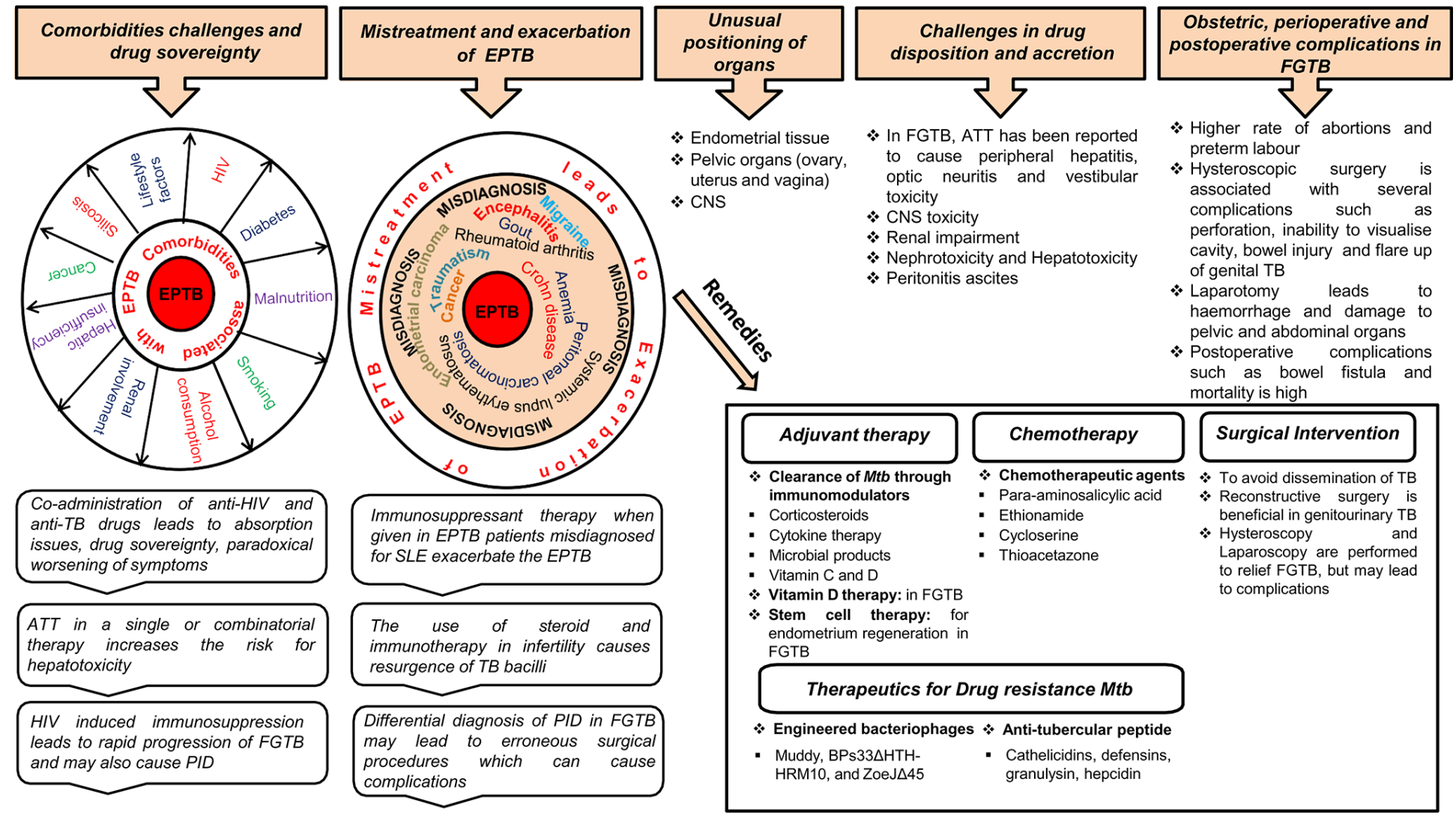

FIGURE 2 | Treatment challenges and remedies for EPTB, in particular, FGTB. Various comorbidity challenges associated with EPTB are depicted. The risk of EPTB, particularly FGTB, occurrence increases in a comorbid condition depending on the severity of immunosuppression associated with these diseases. Coadministration of drugs results in drug sovereignty, toxicity, absorption issues, and paradoxical reactions in the body, which can further exacerbate the condition. EPTB misdiagnosis and subsequent mistreatment suppress the immune system to such an extent that it increases the bacterial prepotency of spreading to

other organs (example genital organs) and exacerbation. Differential diagnosis in FGTB leads to erroneous surgical procedures, which can cause complications. ATT treatment in EPTB, in particular FGTB, faces drug disposition and accretion challenges. The unusual positioning of infected organs in EPTB illustrate treatment challenges, especially in meningitis TB, ovarian TB, urogenital TB, and endometrial TB. Due to the inaccessibility of organs in FGTB, surgical interventions are required to avoid dissemination of $M$. tuberculosis; however, several perioperative complications have been observed during surgery. Erroneous surgical procedures and mistreatment lead to obstetric and postoperative complications. Stem cell therapy, chemotherapy, vitamin D therapy, and surgical interventions can be beneficial in FGTB, whereas adjuvant therapy is known to be effective in EPTB, and engineered bacteriophages and antitubercular peptides are used for drug-resistant TB. 
ITGAVB3 ( $\alpha v \beta 3)$, MUC-1 (Mucin-1), and MECA79, as well as hormones expressed during implantation $(90,91)$ (Figure 3). FGTB infection is found to alter the endometrial milieu and, thus, the UR, by causing immune modulation, endocrine disruption, activation of antiphospholipids antibodies, and microthrombosis, which leads to RIF, a major cause of infertility (92). FGTB significantly alters the level of ITGAVB3, MECA79, CDH1, MUC-1, and VEGF, leading to RIF (90). ITGAVB3 is essential for implantation, and its expression is reduced in both FGTB and unexplained recurrent pregnancy loss $(90,91)$. Additionally, an aberrant (reduced) expression of LIF has been reported in the endometrium in FGTB. The concentration of LIF is higher in fertile women compared to infertile females (93). LIF can activate signal transducers and activators of transcription 3 (STAT3) through a signaling cascade mechanism, which regulates UR and is further required for the transcription of VEGF, an angiogenic factor whose role during pregnancy is well studied $(88,90,94,95)$. FGTB lowers VEGF expression; thus creating an unfavorable environment for embryonic implantation (90). On the contrary, high VEGF levels contribute to the pathogenesis of EPTB; therefore, anti-VEGF agents are used in TB to prevent bacterial dissemination $(96,97)$. TB bacilli show an antigonadotropic effect in FGTB, impeding the production of progesterone and human chorionic gonadotropin (98). In FGTB, luteinizing hormone (LH) and follicle stimulating hormone (FSH) levels are high, and inhibin levels are very low (99). Inhibin is considered to be a more sensitive marker of ovarian reserve in FGTB compared to FSH $(99,100)$. Latent FGTB not only interferes with implantation in the basal endometrial layer, but also lowers the level of two ovarian markers, i.e., antimullerian hormone and antral follicle count (101). Furthermore, it has been observed that FGTB lowers the oocyte yield and the ovarian reserve (101).

Cytokine production differs in PTB and EPTB patients; females with normal pregnancy have been observed to have Th2-type cytokine milieu, whereas there has been shown to be an increased production of Th1-type cytokines in unexplained recurrent abortions (102, 103). The inflammatory environment in the endometrium prompts the preponderance of adverse cytokines and antibodies of the Th1 repertoire, making it nonreceptive to

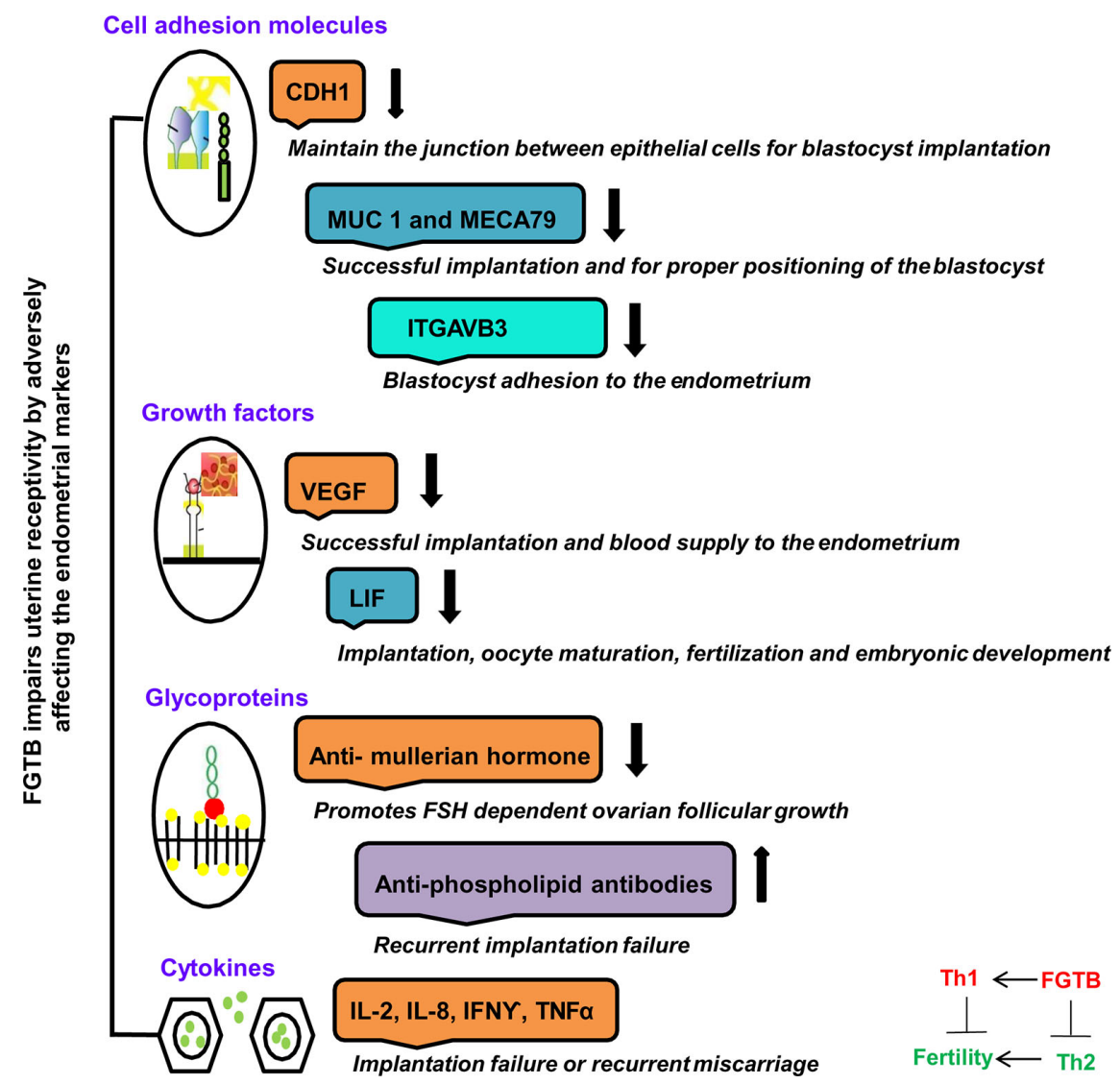

FIGURE 3 | FGTB: Immune dysregulation compromises female fertility. The impact of FGTB on female fertility is depicted. FGTB adversely affects uterine receptivity through immune dysregulation. Various cell adhesion molecules, growth factors, glycoproteins, and cytokines mentioned here are potential biomarkers of uterine receptivity and for successful placentation. FGTB lowers the level of CDH1, MUC1, MECA79, and ITGAVB3, leading to recurrent implantation failure. Similarly, FGTB pares down the levels of VEGF and LIF, which are required for successful placentation, thus creating an unfavorable environment for embryonic implantation. Glycoproteins and cytokines are also required for embryonic development. FGTB also affects embryonic development through upregulating proinflammatory cytokine expression and antiphospholipid antibodies as well as by lowering anti-inflammatory cytokine expression and ovarian reserve markers, such as the antimullerian hormone. 
the embryo, thereby causing an implantation failure (92). However, $\mathrm{T}$ regulatory cells, a subset of $\mathrm{CD}^{+} \mathrm{T}$ cells limit the adaptive immune response and contribute to the persistence of chronic infection. Immune dysregulation has been reported in patients who have a past or present history of EPTB as observed by an increased production of $\mathrm{T}$ regulatory cells, high levels of IL-17, and $\mathrm{CD}^{+}$lymphocyte activation $(104,105)$.

\section{NRS AND FGTB: POTENTIAL MARKERS AND DRUG TARGETS}

This review aims to accentuate three major points: (i) the diagnostic and treatment challenges of EPTB, particularly FGTB; (ii) the need for new therapeutics and diagnostics of EPTB, particularly FGTB; and (iii) the demand for FGTB biomarkers as a point-of-care diagnostic. NRs appear to be major potential therapeutic targets owing to their roles being reported as both pro-TB and anti-TB
(Figure 4). NRs are ligand-activated transcriptional factors that act as molecular switches and can govern many physiological processes, such as metabolism, reproduction, and development. The superfamily of NRs shares a common structure containing an amino terminal domain, a conserved DNA-binding domain (DBD), a hinge region, and a ligand-binding domain (LBD) at the carboxy terminal. The amino terminal domain includes the activator function-1 region (AF-1), which interacts with several coregulatory proteins and is also a site for various posttranslational modification. The DBD is conserved and has two subdomains (for DNA binding and receptor dimerization), each containing 4 cysteine residues that coordinate with a zinc ion to form zinc finger motif. The hinge region consists of a nuclear localization signal, and the LBD harbors another activation function domain (AF-2) that can interact directly with coregulator proteins (106). NRs can exist as monomer, homodimer, and heterodimer that recognize a specific DNA sequence on the target genes known as response elements. NRs are classified into three categories based on

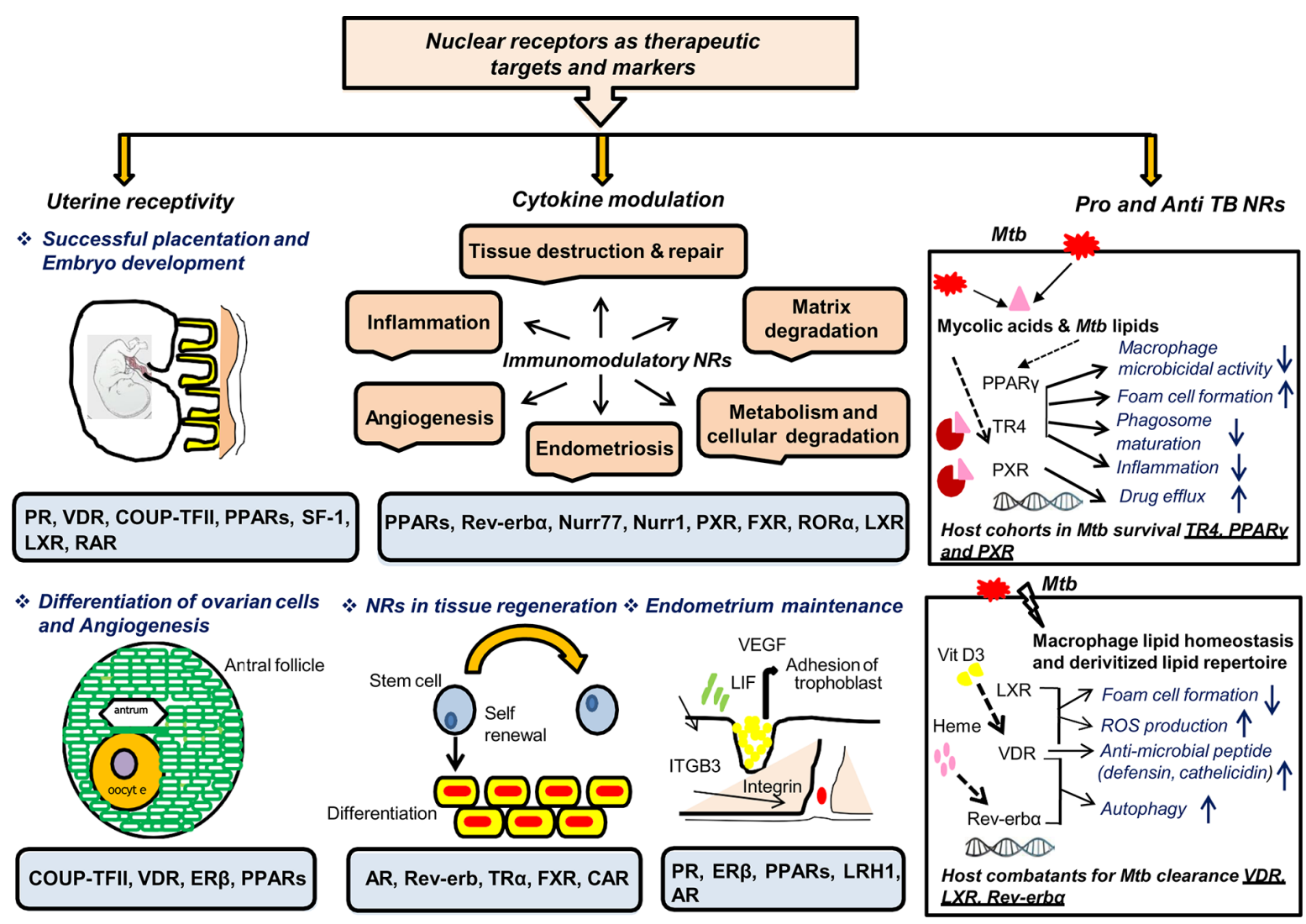

FIGURE 4 | NRs are potential therapeutic targets and markers. NRs have many roles in TB, which makes them potential therapeutic targets for combating FGTB. NRs have been reported in female fertility; for example PR, VDR, COUP-TF, PPARs, SF-1, and LXR are essential for maintaining uterine receptivity through successful placentation and embryonic development. NRs such as COUP-TF, VDR, ERR, and PPARs play an important role in differentiation of ovarian cells and angiogenesis. NRs such as PR, ERB, PPARs, LRH1, and AR are reported in endometrium maintenance. NRs are also good immuno-modulators that may act either directly to combat the compromised tissue's regenerative capacity or indirectly via CM to repair damaged tissues. NRs such as AR, Rev-erb, TR $\alpha$, FXR, and CAR are reported for tissue regeneration, whereas PPARs, Rev-erb $\alpha$, Nurr77, Nurr1, PXR, FXR, ROR $\alpha$, and LXR are known to modulate different cytokines' milieu. Additionally, NRs enhance the self-renewing and differentiation capacity of transcription factors through direct modulation. NRs should be considered as TB biomarkers owing to their reported roles in both therapeutics and pathogenesis. NRs such as TR4, PPAR $\gamma$, and PXR are considered as host cohorts in M. tuberculosis survival. Conversely, NRs such as VDR, LXR, and Rev-erb $\alpha$ are considered as good host combatants for M. tuberculosis clearance. 
the ligand variability: class I constitutes the endocrine receptors, class II includes orphan receptors, and class III comprises adopted orphan receptors. The endocrine receptors recognize steroid molecules and vitamins as their ligands and possess a high affinity toward them. The orphan receptors are those for which no endogenous ligand has been deciphered, and the adopted orphans are those whose ligands have been recently identified, and they bind to low-affinity dietary lipids. As various biological processes are regulated by NRs, pharmacological inhibition or dysregulation of them can lead to various diseases, including cancer, metabolic disorders, infertility, and neurodegeneration. They also play a significant role in infectious disease biology as many pathogens, for their own advantage, can modulate NRs either by interfering with their transcriptional activity or by changing their function. NRs have been studied in macrophage response to infectious disease, which also shows the potential role of NRs in combating infectious disease (107). Our earlier studies show a heterologous and noncanonical ligand receptor pairing, which clearly demonstrates that M. tuberculosis engage NRs (108-110). NRs, such as testicular receptor (TR4), peroxisome proliferator activated receptor (PPAR $\gamma$ ), and pregnane $\mathrm{X}$ receptor (PXR), enhance $M$. tuberculosis survival by subverting the host innate immune defense mechanism and may increase the risk of dissemination $(108,109,111)$. Our group has shown that $M$. tuberculosis cell wall lipids can crosstalk with NRs, such as PPAR $\gamma$, TR4, and PXR. These NRs are involved in the formation of lipid-enriched foamy macrophages inside the host cell, which further enhances $M$. tuberculosis survival and subverts the immune response by abrogating the phagolysosomal fusion, inhibiting the secretion of proinflammatory cytokines and abating apoptosis. Furthermore, our group also reports that PXR causes TB drug nonresponsiveness in human macrophages by virtue of modulating drug efflux transporters (111). It has been observed that knockout of PPAR $\gamma$ in a mouse model reduces the growth of M. tuberculosis, lowers granulomatous infiltration, and enhances secretion of the proinflammatory cytokines (112). Moreover, NRs, such as vitamin $\mathrm{D}$ receptor (VDR) (113), Rev-erb $\alpha$ (114), and liver $\mathrm{X}$ receptor (LXR) (115), help with $M$. tuberculosis clearance. Interestingly, EPTB patients with multidrug-resistant TB have lower vitamin D levels (116). TR4 is identified as a marker for early TB detection in rhesus macaques, demonstrating that NRs are likely to make good biomarkers for TB (117). The expression level of TR4 is linked with severity of disease progression in the PBMCs of M. tuberculosisinfected rhesus macaques. Correspondingly, NRs can be modulated by small molecules, which allows them to be a potential therapeutic drug target. NRs also may have a role in EPTB, particularly FGTB which needs to be addressed further.

The three chief challenges pertaining to FGTB are UR, ER, and CM. These three factors are required for maintaining female fertility; their dysregulation, either directly or indirectly, leads to fertility issues. FGTB, either directly or indirectly, modulates UR and ER or CM, respectively; thereby, causing RIF. As mentioned before, NRs also play multifarious roles in female reproduction and in sustaining viable pregnancies (Table 3). Any perturbations in the expression of NRs could lead to spontaneous abortions. NRs, such as liver receptor homolog 1
(LRH1), retinoic acid receptor (RAR), chicken ovalbumin upstream promoter (COUP-TFII), steroidogenic factor (SF-1), androgen receptor (AR), LXR, VDR, progesterone receptor (PR), estrogen receptor $(\mathrm{ER} \beta)$, and PPARs have been reported for successful uterine implantation and endometrium maintenance. VDR has also been reported to be important for the differentiation of granulosa cells. The NR LRH1 is reported to be important for mouse fertility (118), ovulation, and ovarian steroidogenesis $(119,120)$. RAR is involved in early embryonic development (121). COUP-TFII is required for placental development and angiogenesis $(122,123)$. SF-1 is reported for folliculogenesis and in the process of ovulation with its absence in granulosa cells leading to impaired ovulation $(124,125)$. AR signaling is essential for endometrial function, whereas its perturbation leads to reproductive failure (126). LXR modulates ovarian endocrine and exocrine function and uterus contractility (127). VDR expression increases during pregnancy and helps with reproductive function (128). Vitamin D has roles in folliculogenesis, differentiation, luteinization, and steroidogenesis as well as altering antimullerian hormone signaling and progesterone production (129). Vitamin D deficiency in pregnancy increases the fortuity of preterm birth and preeclampsia $(130,131)$. PR signaling is essential for the initiation and maintenance of pregnancy (132). ER $\beta$ is essential for maintaining the endometrium quiescence and vasculature (133). PPARs are essential for trophoblast invasion, decidualization, tissue remodeling, ovarian function, and placental formation (134-136). Additionally, circadian rhythm disturbance is reported to affect female fertility (137). Rev-erb is a circadian NR, which maintains the circadian rhythm (138) and may have a role in female fertility. Because NRs play crucial roles in female reproduction, they could make good therapeutic targets to combat female infertility.

RIF occurs due to compromised ER capacity; therefore, stem cell therapy for ER could be helpful. Many NRs have gained

TABLE 3 | Role of Nuclear receptors in female reproduction.

\begin{tabular}{ll}
$\begin{array}{l}\text { Nuclear } \\
\text { Receptors }\end{array}$ & \multicolumn{1}{c}{ Functions in Female Reproduction } \\
\hline LRH1 & Essential for ovarian steroidogenesis and ovulation \\
PR & Implantation, decidualization, and preventing endometriosis \\
ER $\alpha$ & Endometriosis progression \\
ER $\beta$ & Maintenance of endometrium quiescence and vasculature \\
SF-1 & Development of reproductive tissue, ovulation, and \\
VDR & folliculogenesis \\
PPAR $\alpha$ & Differentiation of granulosa cells, folliculogenesis, luteinization, \\
PPAR $\beta$ & and steroidogenesis \\
PPAR $\gamma$ & Proliferation and differentiation of ovarian cells \\
Implantation and decidualization \\
RAR & Trophoblast invasion and placental formation, decidualization, \\
Rev-erb & and preventing endometriosis \\
COUP-TFII & Maintenance of endometrium physiology \\
LXR & Embryonic development, growth, and reproduction \\
& Regulating the circadian rhythm \\
& Placental development and angiogenesis
\end{tabular}


attention in stem cell biology (139-142); estrogen receptor $(\mathrm{ER} \alpha), \mathrm{PR}$, and PPAR $\gamma$ are all implicated in endometriosis (143-146); and AR, thyroid receptor (TR), farnesoid X receptor (FXR), Rev-erb, and constitutive androstane receptor (CAR) are reported in tissue regeneration (147-152). Female fertility is compromised due to endometriosis. NRs are known to modulate endometriosis; for example, loss of PR expression leads to endometriotic tissue becoming resistant to progesterone, leading to endometriosis (146). PR helps to relieve pain in endometriosis by limiting inflammation and the growth of endometriotic tissue PPARs and retinoid X receptor alpha are expressed in abortive trophoblastic tissue and are upregulated in extra villous trophoblast in recurrent miscarriages $(153,154)$.

M. tuberculosis modulates various cytokines' milieu, such as interferon $\gamma$ (IFN $\gamma$ ) and interleukin- (IL2) in the endometrium and TNF $\alpha$, IL-6, IL-4, and IL- 8 in the blood $(155,156)$. Additionally, administration of IFN $\gamma, \mathrm{TNF} \alpha$, and IL-2 is reported to cause abortions in pregnant mice $(102,157,158)$. Moreover, IL-1 $\beta$ is shown to promote endometriosis and angiogenesis (159, 160). Conversely, IL-6 and IL-10 are reported to have increased production in normal pregnancy compared to spontaneous abortion (103). Various proinflammatory, anti-inflammatory, and pleiotropic NRs, such as retinoic acid receptor-related orphan receptor, nuclear receptor related (Nurr) 77, Nurr1, ROR $\alpha$, PXR, FXR, PPAR $\alpha$, LXR, Rev-erbo, and PPARs, are known as immune modulators as they can modulate different cytokines' milieu (114, 161-167). LXR is known to inhibit proinflammatory cytokine expression and is also responsible for maternal-fetal cholesterol transport; there is also a reduction in LXR expression in miscarriages (168, 169). Additionally, FGTB modulates pregnancy-related hormones, such as human chorionic gonadotropin and progesterone, which are known to function via their cognate endocrine receptors (98). Taken together, NRs seem to be a promising target to combat FGTB by addressing the issues of UR, ER, and CM. Extensive knowledge about the expression and function of the NRs in FGTB is lacking and needs to be addressed.

FGTB modulates the localized endometrial immune repertoire, which has been reported to modulate UR. There are various reports illustrating the function of the endometrial immune repertoire in recurrent spontaneous miscarriage (170), polycystic ovarian syndrome (171), endometriosis (172), and unexplained infertility (173). Given the reported role of NRs in the regulation of uterine implantation and CM as well as being cognate to pregnancy-related hormones, for example, estrogen, progesterone, human chorionic gonadotropin, and human placental lactogen, which function via estrogen receptor, PR, and VDR, respectively (174-178), they are good potential targets to alleviate the disease. NRs could be excellent host-directed targets in FGTB as evident from previous reports of NRs in TB. $M$. tuberculosis can modulate the expression of NRs by certain crosstalk with its lipid repertoire. It would be interesting to see whether M. tuberculosis components interfere or modulate the interaction of pregnancy-related hormones with their cognate endocrine receptors. It would be interesting to decipher whether the $M$. tuberculosis components also relay their effect through orphan or adopted orphan receptors.

\section{DISCUSSION}

Globally, EPTB and, in particular, FGTB are growing problems with increasing rates of morbidity and mortality worldwide. FGTB represents the most perilous form of EPTB and is the leading cause of infertility and recurrent implantation failure in females. FGTB cases are asymptomatic in early stages, and untreated FGTB can cause permanent sterility through endometrial destruction and tubal damage. FGTB diagnosis is arduous because of varied clinical presentations, misdiagnosis, associated comorbidities, arduousness in acquiring of clinical samples, poor sensitivity, it is often asymptomatic and paucibacillary, emergence of drug resistance, lack of point of care, impenetrable sites, and abstruse positioning of the organs. Likewise, the treatment of FGTB faces formidable challenges due to drug toxicity; HIV coinfection; obstetric, perioperative, and postoperative complications; reactivation; and emergence of drug-resistant bacteria. Our review rolls out the possible remedies to prevent FGTB by precluding several of these challenges and also highlights the need for exaction of biomarkers in FGTB.

It is imperative to understand that FGTB adversely affects UR and causes immune modulation, which promptly leads to abortions and also reduces the chances of conception. We emphasize the imperative mechanism of FGTB-associated female infertility by highlighting the three major challenges, i.e., UR, ER, and CM. FGTB adversely affects various endocrine hormones (progesterone, estrogen, and human chorionic gonadotropin), cytokines, growth factors (LIF and VEGF), and cell adhesion molecules (ITGAVB3, MECA79, CDH1 and MUC-1), which are responsible for the maintenance of successful pregnancy. We epitomize the need to identify the molecular switches at the interface of FGTB and mechanisms associated with female infertility.

Given the above challenges in FGTB, there is an exigent need to identify FGTB-specific biomarkers from accessible samples. NRs have been reported as both pro- and anti-TB but have gained less attention in FGTB. They are reported to modulate female fertility and stem cell plasticity and are also known as immune modulators. We attempt to invoke interest in the exploration of NRs as a novel therapeutic target in FGTBassociated female infertility and as a potential biomarker. NRs, which are cognate to pregnancy-related hormones (estrogen, progesterone, and human chorionic gonadotropin) and have been cited in female reproduction and regeneration, prompt us to postulate them as a potential player and target to combat FGTB-associated female infertility by addressing the issues of UR, ER, and CM.

The topic is of immediate importance because of the abrupt increase in disease severity, drug resistance, and lack of a knowledge base of the major diagnostic and treatment challenges, which leads to exacerbation in FGTB. Although a 
large number of biosignatures and mechanisms have been reported in FGTB, there is a paucity of specific targets and biomarkers. Our review provides the conceptual advance; it postulates the role of NRs as a potential target and biomarker in FGTB. The description is comprehensive and is factual. Fostering innovative research is required to (i) develop highly permeable, safe, and nontoxic drugs with a novel mechanism of action and target; (ii) identify biomarkers and point-of-care diagnostics; and (iii) develop a strategy to shorten the treatment regimens and reduce treatment-related functional disability.

\section{AUTHOR CONTRIBUTIONS}

SG and PG designed the study. SG and PG wrote the review. PG contributed to the overall supervision of the manuscript. All authors contributed to the article and approved the submitted version.

\section{REFERENCES}

1. Sharma S, Mohan A. Extrapulmonary tuberculosis. Indian J Med Res (2004) 120:316-353.

2. World Health Organization Global Tuberculosis Report. (2019) 1-297.

3. Lee JY. Diagnosis and treatment of extrapulmonary tuberculosis. Tuberc Respir Dis (2015) 78:47-55. doi: 10.4046/trd.2015.78.2.47

4. Qian X, Nguyen DT, Lyu J, Albers AE, Bi X, Graviss EA. Risk factors for extrapulmonary dissemination of tuberculosis and associated mortality during treatment for extrapulmonary tuberculosis. Emerg Microbes Infect (2018) 7:1-14. doi: 10.1038/s41426-018-0106-1

5. Jalali SM, Mashuri N, Tamannaie Z, Jesmi F, Pazouki A. Peritoneal Tuberculosis: An Uncommon Disease Calling for Close Scrutiny. Arch Clin Infect Dis (2013) 8:e16672. doi: 10.5812/archcid.16672

6. Hopewell PC. Overview of clinical tuberculosis in Tuberculosis. in: Bloom B.R, editor. Pathogenesis, Protection, and Control. Washington DC: American Society for Microbiology (1994) 25-46. doi: 10.1128/9781555 818357.ch3

7. Polena H, Boudou F, Tilleul S, Dubois-Colas N, Lecointe C, Rakotosamimanana N, et al. Mycobacterium tuberculosis exploits the formation of new blood vessels for its dissemination. Sci Rep (2016) 6:33162. doi: $10.1038 /$ srep33162

8. Muneer A, Macrae B, Krishnamoorthy S, Zumla A. Urogenital tuberculosis - epidemiology, pathogenesis and clinical features. Nat Rev Urol (2019) 16:573-98. doi: 10.1038/s41585-019-0228-9

9. Purohit MR, Purohit R, Mustafa T. Patient Health Seeking and Diagnostic Delay in Extrapulmonary Tuberculosis: A Hospital Based Study from Central India. Tuberc Res Treat (2019) 2019:4840561. doi: 10.1155/2019/ 4840561

10. Mirsaeidi M, Sadikot RT. Patients at high risk of tuberculosis recurrence. Int J Mycobacteriol (2018) 7:1-6. doi: 10.4103/ijmy.ijmy_164_17

11. Eftekhar M, Pourmasumi S, Sabeti P, Aflatoonian A, Sheikhha MH. Mycobacterium tuberculosis infection in women with unexplained infertility. Int J Reprod BioMed (2015) 13:749-54. doi: 10.29252/ ijrm.13.12.749

12. Duggal S, Duggal N, Hans C, Mahajan R. Female genital TB and HIV coinfection. Indian J Med Microbiol (2009) 27:361 - 363. doi: 10.4103/02550857.55461

13. Al-Hakeem M, Schneider A. Genital tuberculosis: A rare cause of vulvovaginal discharge and swelling. J Microbiol Infect Dis (2013) 03:1413. doi: 10.5799/ahinjs.02.2013.03.0097

14. Sharma JB, Sneha J, Singh UB, Kumar S, Roy KK, Singh N, et al. Comparative Study of Laparoscopic Abdominopelvic and Fallopian Tube Findings Before and After Antitubercular Therapy in Female Genital Tuberculosis With Infertility. J Minim Invasive Gynecol (2016) 23:215-22. doi: 10.1016/j.jmig.2015.09.023

\section{FUNDING}

This work was supported by the Council of Scientific and Industrial Research (CSIR) RC project (OLP115) to PG. This work is also supported by the Department of Biotechnology, Ministry of Science and Technology, National Bioscience Award project (GAP-0162) to PG. We thank IMTECH, a CSIR laboratory, for the facilities and financial support. The funders had no role in study design, data collection, or interpretation or in any decision to submit the work for publication.

\section{ACKNOWLEDGMENTS}

We express regret for not citing the work of many our colleagues due to space constraints.

15. Namavar Jahromi B, Parsanezhad ME, Ghane-Shirazi R. Female genital tuberculosis and infertility. Int J Gynecol Obstet (2001) 75:269-72. doi: 10.1016/S0020-7292(01)00494-5

16. Shahzad S. Investigation of the prevalence of female genital tract tuberculosis and its relation to female infertility:An observational analytical study. Iran J Reprod Med (2012) 10:581-8.

17. Parikh FR, Nadkarni SG, Kamat SA, Naik N, Soonawala SB, Parikh RM. Genital tuberculosis-a major pelvic factor causing infertility in Indian women. Fertil Steril (1997) 67:497-500. doi: 10.1016/S0015-0282(97) 80076-3

18. Tripathy SN, Tripathy SN. Infertility and pregnancy outcome in female genital tuberculosis. Int J Gynecol Obstet (2002) 76:159-63. doi: 10.1016/ S0020-7292(01)00525-2

19. Gatongi DK, Gitau G, Kay V, Ngwenya S, Lafong C, Hasan A. Female genital tuberculosis. Obstet Gynaecol (2005) 7:75-9. doi: 10.1576/toag.7.2.075.27000

20. Das P, Ahuja A, Gupta SD. Incidence, etiopathogenesis and pathological aspects of genitourinary tuberculosis in India: A journey revisited. Indian J Urol (2008) 24:356-61. doi: 10.4103/0970-1591.42618

21. Hasanzadeh M, Naderi HR, Hoshyar AH, Shabane S, Shahidsales S. Female genital tract tuberculosis presenting as ovarian cancer. J Res Med Sci Off J Isfahan Univ Med Sci (2014) 19:184-9.

22. Gungorduk K, Ulker V, Sahbaz A, Ark C, Ismet Tekirdag A. Postmenopausal Tuberculosis Endometritis. Infect Dis Obstet Gynecol (2007) 2007:27028. doi: 10.1155/2007/27028

23. Margolis K, Wranz P, Kruger T, Joubert J, Odendaal H. Genital tuberculosis at Tygerberg Hospital-prevalence, clinical presentation and diagnosis. South Afr Med J Suid-Afr Tydskr Vir Geneeskd (1992) 81:12-15.

24. Qureshi R, Samad S, Hamid R, Lakha S. Female genital tuberculosis revisted. JPMA J Pak Med Assoc (2001) 51:16-18.

25. Samal S, Gupta U, Agarwal P. Menstrual disorders in genital tuberculosis. J Indian Med Assoc (2000) 98:126-7, 129.

26. Vadwai V, Boehme C, Nabeta P, Shetty A, Alland D, Rodrigues C. Xpert MTB/RIF: a new pillar in diagnosis of extrapulmonary tuberculosis? J Clin Microbiol (2011) 49:2540-5. doi: 10.1128/JCM.02319-10

27. Bartoloni A, Strohmeyer M, Bartalesi F, Messeri D, Tortoli E, Farese A, et al. Evaluation of a rapid immunochromatographic test for the serologic diagnosis of tuberculosis in Italy. Clin Microbiol Infect (2003) 9:632-9. doi: 10.1046/j.1469-0691.2003.00574.x

28. Maertzdorf J, Kaufmann SH, Weiner J. Toward a Unified Biosignature for Tuberculosis. Cold Spring Harb Perspect Med (2015) 5:a018531. doi: 10.1101/cshperspect.a018531

29. Berry MPR, Graham CM, McNab FW, Xu Z, Bloch SAA, Oni T, et al. An Interferon-Inducible Neutrophil-Driven Blood Transcriptional Signature in Human Tuberculosis. Nature (2010) 466:973-7. doi: 10.1038/nature09247

30. Maertzdorf J, Ota M, Repsilber D, Mollenkopf HJ, Weiner J, Hill PC, et al. Functional Correlations of Pathogenesis-Driven Gene Expression Signatures 
in Tuberculosis. PloS One (2011) 6:e26938. doi: 10.1371/journal. pone. 0026938

31. Duffy FJ, Weiner JI, Hansen S, Tabb DL, Suliman S, Thompson E, et al. Immunometabolic Signatures Predict Risk of Progression to Active Tuberculosis and Disease Outcome. Front Immunol (2019) 10:527. doi: 10.3389/fimmu.2019.00527

32. Weiner J, Maertzdorf J, Sutherland JS, Duffy FJ, Thompson E, Suliman S, et al. Metabolite changes in blood predict the onset of tuberculosis. Nat Commun (2018) 9:5208. doi: 10.1038/s41467-018-07635-7

33. Walzl G, Mcnerney R, de Plessis N, Bates M, McHugh TD, Chegou NN, et al. Tuberculosis: advances and challenges in development. Lancet Infect Dis (2018) 18:e119-e210. doi: 10.1016/S1473-3099(18)30111-7

34. Roe JK, Thomas N, Gil E, Best K, Tsaliki E, Morris-Jones S, et al. Blood transcriptomic diagnosis of pulmonary and extrapulmonary tuberculosis. JCI Insight (2016) 1:e87238. doi: 10.1172/jci.insight.87238

35. MacLean E, Broger T, Yerlikaya S, Fernandez-Carballo BL, Pai M, Denkinger CM. A systematic review of biomarkers to detect active tuberculosis. Nat Microbiol (2019) 4:748-58. doi: 10.1038/s41564-0190380-2

36. Fortún J, Martín-Dávila P, Gómez-Mampaso E, Vallejo A, Cuartero C, González-García A, et al. Extra-pulmonary tuberculosis: a biomarker analysis. Infection (2014) 42:649-54. doi: 10.1007/s15010-014-0602-8

37. Kumar NP, Anuradha R, Andrade BB, Suresh N, Ganesh R, Shankar J, et al. Circulating Biomarkers of Pulmonary and Extrapulmonary Tuberculosis in Children. Clin Vaccine Immunol (2013) 20:704-11. doi: 10.1128/CVI.00 038-13

38. Elzein F, Elzein A, Mohammed N, Alswailem R. Miliary tuberculosis mimicking systemic lupus erythematosus flare. Respir Med Case Rep (2018) 25:216-9. doi: 10.1016/j.rmcr.2018.09.005

39. Boss JD, Shah CT, Oluwole O, Sheagren JN. TB Peritonitis Mistaken for Ovarian Carcinomatosis Based on an Elevated CA-125. Case Rep Med (2012) 2012:215293-3. doi: 10.1155/2012/215293

40. Seo H, Lee S, So H, Kim D, Kim S-O, Soh JS, et al. Temporal trends in the misdiagnosis rates between Crohn's disease and intestinal tuberculosis. World J Gastroenterol (2017) 23:6306-14. doi: 10.3748/wjg.v23.i34.6306

41. Sharma JB. Current Diagnosis and Management of Female Genital Tuberculosis. J Obstet Gynaecol India (2015) 65:362-71. doi: 10.1007/ s13224-015-0780-z

42. Khanna SR, Kralovic SM, Prakash R. Tuberculous Meningitis in an Immunocompetent Host: A Case Report. Am J Case Rep (2016) 17:97781. doi: $10.12659 /$ ajcr.900762

43. Chapman CB, Whorton CM. Acute Generalized Miliary Tuberculosis in Adults. N Engl J Med (1946) 235:239-48. doi: 10.1056/NEJM194608 222350801

44. Sharma SK, Mohan A, Sharma A. Miliary tuberculosis: A new look at an old foe. J Clin Tuberc Mycobact Dis (2016) 3:13-27. doi: 10.1016/ j.jctube.2016.03.003

45. Vasankari T, Liippo K, Tala E. Overt and Cryptic Miliary Tuberculosis Misdiagnosed until Autopsy. Scand J Infect Dis (2003) 35:794-6. doi: 10.1080/00365540310016961

46. Schubert GE, Haltaufderheide T, Golz R. Frequency of Urogenital Tuberculosis in an Unselected Autopsy Series from 1928 to 1949 and 1976 to 1989. Eur Urol (1992) 21:216-23. doi: 10.1159/000474841

47. Sharma JB, Karmakar D, Kumar R, Shamim SA, Kumar S, Singh N, et al. Comparison of PET/CT with other imaging modalities in women with genital tuberculosis. Int J Gynecol Obstet (2012) 118:123-8. doi: 10.1016/ j.ijgo.2012.02.020

48. Sharma JB, Karmakar D, Hari S, Singh N, Singh SP, Kumar S, et al. Magnetic resonance imaging findings among women with tubercular tubo-ovarian masses. Int J Gynecol Obstet (2011) 113:76-80. doi: 10.1016/j.ijgo. 2010.10.021

49. Sethi S, Dhaliwal L, Dey P, Kaur H, Yadav R, Sethi S. Loop-mediated isothermal amplification assay for detection of Mycobacterium tuberculosis complex in infertile women. Indian J Med Microbiol (2016) 34:322-7. doi: 10.4103/0255-0857.188323

50. Efared B, Sidibé IS, Erregad F, Hammas N, Chbani L, El Fatemi H. Female genital tuberculosis: a clinicopathological report of 13 cases. J Surg Case Rep (2019) 3:rjz083. doi: 10.1093/jscr/rjz083
51. Sharma JB, Roy KK, Pushparaj M, Karmakar D, Kumar S, Singh N. Increased Difficulties and Complications Encountered During Hysteroscopy in Women with Genital Tuberculosis. J Minim Invasive Gynecol (2011) 18:660-5. doi: 10.1016/j.jmig.2011.05.008

52. Grace GA, Devaleenal DB, Natrajan M. Genital tuberculosis in females. Indian J Med Res (2017) 145:425-36. doi: 10.4103/ijmr.IJMR_1550_15

53. Neonakis IK, Spandidos DA, Petinaki E. Female genital tuberculosis: A review. Scand J Infect Dis (2011) 43:564-72. doi: 10.3109/00365548. 2011.568523

54. Sah SK, Shi X, Du S, Li X, Li CH, Shah S, et al. CT findings and analysis for misdiagnosis of female pelvic tuberculosis. Radiol Infect Dis (2017) 4:19-25. doi: 10.1016/j.jrid.2016.04.001

55. Sharma S, Dutta S, Yadav A,K, Mandal A. A Rare Case of Cervical Tuberculosis Masquerading as Carcinoma Cervix. Ann Woman Child Health (2016) 2:C20-3.

56. Gupta B, Shree S, Rajaram S, Goel N. Genital tuberculosis: Unusual presentations. Int J Mycobacteriol (2016) 5:357-9. doi: 10.1016/j.ijmyco. 2016.06.017

57. Sharma JB, Kriplani A, Sharma E, Sharma S, Dharmendra S, Kumar S, et al. Multi drug resistant female genital tuberculosis: A preliminary report. Eur J Obstet Gynecol Reprod Biol (2017) 210:108-15. doi: 10.1016/j.ejogrb. 2016.12.009

58. Bhanothu V, Theophilus JP, Rozati R. Use of Endo-Ovarian Tissue Biopsy and Pelvic Aspirated Fluid for the Diagnosis of Female Genital Tuberculosis by Conventional versus Molecular Methods. PloS One (2014) 9:e98005. doi: 10.1371/journal.pone.0098005

59. Yousef AI, Ismael MF, Elshora AE, Abdou HE. Pulmonary tuberculosis in patients with chronic renal failure at Zagazig University Hospitals. Egypt $J$ Chest Dis Tuberc (2014) 63:187-92. doi: 10.1016/j.ejcdt.2013.11.002

60. Gurumurthy P, Ramachandran G, Kumar AKH, Rajasekaran S, Padmapriyadarsini C, Swaminathan S, et al. Malabsorption of Rifampin and Isoniazid in HIV-Infected Patients With and Without Tuberculosis. Clin Infect Dis (2004) 38:280-3. doi: 10.1086/380795

61. Rajasekaran S, Khandelwal G. Drug therapy in spinal tuberculosis. Eur Spine J Off Publ Eur Spine Soc Eur Spinal Deform Soc Eur Sect Cerv Spine Res Soc (2013) 22 Suppl 4:587-93. doi: 10.1007/s00586-012-2337-5

62. Sharma P, Tyagi P, Singla V, Bansal N, Kumar A, Arora A. Clinical and biochemical profile of tuberculosis in patients with liver cirrhosis. J Clin Exp Hepatol (2015) 5:8-13. doi: 10.1016/j.jceh.2015.01.003

63. Jullien S, Jain S, Ryan H, Ahuja V. Six-month therapy for abdominal tuberculosis. Cochrane Database Syst Rev (2016) 11:CD012163. doi: 10.1002/14651858.CD012163.pub2

64. Scharer L, JP S. Serum Transaminase Elevations and Other Hepatic Abnormalities in Patients Receiving Isoniazid. Ann Intern Med (1969) 71:1113-20. doi: 10.7326/0003-4819-71-6-1113

65. Mitchell JR, Zimmerman HJ, Ishak KG, Thorgeirsson UP, Timbrell JA, Snodgrass WR, et al. Isoniazid Liver Injury: Clinical Spectrum, Pathology, and Probable Pathogenesis. Ann Intern Med (1976) 84:181-92. doi: 10.7326/ 0003-4819-84-2-181

66. Ramappa V, Aithal GP. Hepatotoxicity Related to Anti-tuberculosis Drugs: Mechanisms and Management. J Clin Exp Hepatol (2013) 3:37-49. doi: $10.1016 /$ j.jceh.2012.12.001

67. Amedia C, Oettinger C. Unusual presentation of tuberculosis in chronic hemodialysis patients. Clin Nephrol (1977) 8:363-6.

68. Milburn H, Ashman N, Davies P, Doffman S, Drobniewski F, Khoo S, et al. Guidelines for the prevention and management of Mycobacterium tuberculosis infection and disease in adult patients with chronic kidney disease. Thorax (2010) 65:557-70. doi: 10.1136/thx.2009.133173

69. Chen D, Yang Z, Yang Y, Zhan Z, Yang X. A Rare Case of Disseminated Tuberculosis of the Bone Marrow in Systemic Lupus Erythematosus: Case Report. Med (Baltimore) (2016) 95:e3552-2. doi: 10.1097/MD.0000000 000003552

70. Nau R, Sörgel F, Eiffert H. Penetration of Drugs through the BloodCerebrospinal Fluid/Blood-Brain Barrier for Treatment of Central Nervous System Infections. Clin Microbiol Rev (2010) 23:858-83. doi: 10.1128/CMR.00007-10

71. Chang C-H, Chen Y-F, Wu V-C, Shu C-C, Lee C-H, Wang J-Y, et al. Acute kidney injury due to anti-tuberculosis drugs: a five-year experience in an 
aging population. BMC Infect Dis (2014) 14:23-3. doi: 10.1186/1471-233414-23

72. Pazhayattil GS, Shirali AC. Drug-induced impairment of renal function. Int $J$ Nephrol Renov Dis (2014) 7:457-68. doi: 10.2147/IJNRD.S39747

73. Beebe A, Seaworth B, Patil N. Rifampicin-induced nephrotoxicity in a tuberculosis patient. J Clin Tuberc Mycobact Dis (2015) 1:13-5. doi: 10.1016/j.jctube.2015.09.001

74. Ilmer M, Bergauer F, Friese K, Mylonas I. Genital Tuberculosis as the Cause of Tuboovarian Abscess in an Immunosuppressed Patient. Infect Dis Obstet Gynecol (2010) 2009:745060. doi: 10.1155/2009/745060

75. Gautam S, Jain A, Akhtar S, Priyadarshini A, Jaiswar SP. Serum Vitamin D Level as a Risk Factor for Female Genital Tuberculosis (FGTB). J Clin Diagn Res (2017) 11:DC18-DC20. doi: 10.7860/JCDR/2017/30084.10636

76. Mahajan N, Naidu P, Kaur S. Insight into the diagnosis and management of subclinical genital tuberculosis in women with infertility. J Hum Reprod Sci (2016) 9:135-44. doi: 10.4103/0974-1208.192043

77. Ballon SC, Clewell WH, Lamb EJ. Reactivation of silent pelvic tuberculosis by reconstructive tubal surgery. Am J Obstet Gynecol (1975) 122:991. doi: 10.1016/0002-9378(75)90363-4

78. Sharma J, Roy K, Pushparaj M, Gupta N, Jain S, Malhotra N, et al. Genital tuberculosis: An important cause of Asherman's syndrome in India. Arch Gynecol Obstet (2008) 277:37-41. doi: 10.1007/s00404-007-0419-0

79. Sharma JB, Mohanraj P, Jain SK, Roy KK. Increased complication rates in vaginal hysterectomy in genital tuberculosis. Arch Gynecol Obstet (2011) 283:831-5. doi: 10.1007/s00404-010-1463-8

80. Al eryani AA, Abdelrub AS, Al Harazi AH. Genital tuberculosis is common among females with tubal factor infertility: Observational study. Alex J Med (2015) 51:321-4. doi: 10.1016/j.ajme.2014.11.004

81. Kulshrestha V, Kriplani A, Agarwal N, Singh UB, Rana T. Genital tuberculosis among infertile women and fertility outcome after antitubercular therapy. Int J Gynecol Obstet (2011) 113:229-34. doi: 10.1016/j.ijgo.2010.12.014

82. Jindal UN, Verma S, Bala Y. Favorable infertility outcomes following antitubercular treatment prescribed on the sole basis of a positive polymerase chain reaction test for endometrial tuberculosis. Hum Reprod (2012) 27:1368-74. doi: 10.1093/humrep/des076

83. Sharma JB, Sharma E, Sharma S, Dharmendra S. Female genital tuberculosis: Revisited. Indian J Med Res (2018) 148:S71-83. doi: 10.4103/ijmr. IJMR_648_18

84. Pang Y, An J, Shu W, Huo F, Chu N, Gao M, et al. Epidemiology of Extrapulmonary Tuberculosis among Inpatients, China, 2008-2017. Emerg Infect Dis J (2019) 25:457-64. doi: 10.3201/eid2503.180572

85. Sethi S, Biswal M, Chatterjee S, Mewara A, Gupta D, Kumar S, et al. Susceptibility pattern among pulmonary and extrapulmonary isolates of Mycobacterium tuberculosis in north India. Afr J Microbiol Res (2012) 6:3696-9. doi: 10.5897/AJMR12.195.

86. Dedrick RM, Guerrero-Bustamante CA, Garlena RA, Russell DA, Ford K, Harris K, et al. Engineered bacteriophages for treatment of a patient with a disseminated drug-resistant Mycobacterium abscessus. Nat Med (2019) 25:730-3. doi: 10.1038/s41591-019-0437-z

87. Khusro A, Aarti C, Agastian P. Anti-tubercular peptides: A quest of future therapeutic weapon to combat tuberculosis. Asian Pac J Trop Med (2016) 9:1023-34. doi: 10.1016/j.apjtm.2016.09.005

88. Vuorela P, Carpén O, Tulppala M, Halmesmäki E. VEGF. its receptors and the Tie receptors in recurrent miscarriage. Mol Hum Reprod (2000) 6:27682. doi: $10.1093 / \mathrm{molehr} / 6.3 .276$

89. Marwood M, Visser K, Salamonsen LA, Dimitriadis E. Interleukin-11 and Leukemia Inhibitory Factor Regulate the Adhesion of Endometrial Epithelial Cells: Implications in Fertility Regulation. Endocrinology (2009) 150:291523. doi: 10.1210/en.2008-1538

90. Subramani E, Madogwe E, Ray CD, Dutta SK, Chakravarty B, Bordignon V, et al. Dysregulated leukemia inhibitory factor and its receptor regulated signal transducers and activators of transcription 3 pathway: a possible cause for repeated implantation failure in women with dormant genital tuberculosis? Fertil Steril (2016) 105:1076-1084. doi: 10.1016/ j.fertnstert.2015.12.015

91. Casals G, Ordi J, Creus M, Fábregues F, Carmona F, Casamitjana R, et al. Osteopontin and $\alpha v \beta 3$ integrin as markers of endometrial receptivity: the effect of different hormone therapies. Reprod BioMed Online (2010) 21:34959. doi: $10.1016 /$ j.rbmo.2010.04.012

92. Chowdhury R, Paine S, Bhattacharjee B, Chatterjee S. Infestation Of Endometrium By Mycobacterium Tuberculosis Bacilli-Cause Of Reproductive Failure. Al Ameen J Med Sci (2010) 3:322-31.

93. Hambartsoumian E. Endometrial Leukemia Inhibitory Factor (LIF) as a Possible Cause of Unexplained Infertility and Multiple Failures of Implantation. Am J Reprod Immunol (1998) 39:137-43. doi: 10.1111/ j.1600-0897.1998.tb00345.x

94. Cheng J-G, Chen JR, Hernandez L, Alvord WG, Stewart CL. Dual control of LIF expression and LIF receptor function regulate Stat3 activation at the onset of uterine receptivity and embryo implantation. Proc Natl Acad Sci (2001) 98:8680-5. doi: 10.1073/pnas.151180898

95. Fedorcsák P, Storeng R. Effects of Leptin and Leukemia Inhibitory Factor on Preimplantation Development and STAT3 Signaling of Mouse Embryos In Vitrol. Biol Reprod (2003) 69:1531-8. doi: 10.1095/biolreprod.103.019034

96. Invernizzi A, Franzetti F, Viola F, Meroni L, Staurenghi G. Optic Nerve Head Tubercular Granuloma Successfully Treated with Anti-VEGF Intravitreal Injections in Addition to Systemic Therapy. Eur J Ophthalmol (2014) 25:270-2. doi: 10.5301/ejo.5000528

97. Oehlers SH, Cronan MR, Scott NR, Thomas MI, Okuda KS, Walton EM, et al. Interception of host angiogenic signalling limits mycobacterial growth. Nature (2015) 517:612-5. doi: 10.1038/nature13967

98. Kumar A, Rattan A. Antigonadotrophic effect of Mycobacterium tuberculosis. Horm Metab Res Horm Stoffwechselforschung Horm Metab (1997) 29:501-3. doi: 10.1055/s-2007-979088

99. Malhotra N, Sharma V, Bahadur A, Sharma JB, Roy KK, Kumar S. The effect of tuberculosis on ovarian reserve among women undergoing IVF in India. Int J Gynaecol Obstet Off Organ Int Fed Gynaecol Obstet (2012) 117:40-4. doi: 10.1016/j.ijgo.2011.10.034

100. Danforth DR, Arbogast LK, Mroueh J, Kim MH, Kennard EA, Seifer DB, et al. Dimeric inhibin: a direct marker of ovarian aging. Fertil Steril (1998) 70:119-23. doi: 10.1016/S0015-0282(98)00127-7

101. Jirge PR, Chougule SM, Keni A, Kumar S, Modi D. Latent genital tuberculosis adversely affects the ovarian reserve in infertile women. Hum Reprod (2018) 33:1262-9. doi: 10.1093/humrep/dey117

102. Makhseed M, Raghupathy R, Azizieh F, Omu A, Al-Shamali E, Ashkanani L. Th1 and Th2 cytokine profiles in recurrent aborters with successful pregnancy and with subsequent abortions. Hum Reprod (2001) 16:221926. doi: 10.1093/humrep/16.10.2219

103. Raghupathy R, Makhseed M, Azizieh F, Omu A, Gupta M, Farhat R. Cytokine production by maternal lymphocytes during normal human pregnancy and in unexplained recurrent spontaneous abortion. Hum Reprod (2000) 15:713-8. doi: 10.1093/humrep/15.3.713

104. de Almeida AS, Fiske CT, Sterling TR, Kalams SA. Increased frequency of regulatory $\mathrm{T}$ cells and $\mathrm{T}$ lymphocyte activation in persons with previously treated extrapulmonary tuberculosis. Clin Vaccine Immunol CVI (2012) 19:45-52. doi: 10.1128/CVI.05263-11

105. Hasan Z, Jamil B, Ashraf M, Islam M, Yusuf MS, Khan JA, et al. ESAT6induced IFNgamma and CXCL9 can differentiate severity of tuberculosis. PloS One (2009) 4:e5158. doi: 10.1371/journal.pone.0005158

106. Weikum ER, Liu X, Ortlund EA. The nuclear receptor superfamily: A structural perspective. Protein Sci (2018) 27:1876-92. doi: 10.1002/pro.3496

107. Leopold Wager CM, Arnett E, Schlesinger LS. Macrophage nuclear receptors: Emerging key players in infectious diseases. PloS Pathog (2019) 15:e1007585. doi: 10.1371/journal.ppat.1007585

108. Bhagyaraj E, Nanduri R, Saini A, Dkhar HK, Ahuja N, Chandra V, et al. Human Xenobiotic Nuclear Receptor PXR Augments Mycobacterium tuberculosis Survival. J Immunol Baltim Md 1950 (2016) 197:244-255. doi: 10.4049/jimmunol.1600203

109. Dkhar HK, Nanduri R, Mahajan S, Dave S, Saini A, Somavarapu AK, Arora A, et al. Mycobacterium tuberculosis keto-mycolic acid and macrophage nuclear receptor TR4 modulate foamy biogenesis in granulomas: a case of a heterologous and noncanonical ligand-receptor pair. J Immunol (2014) 193:295-305. doi: 10.4049/jimmunol.1400092

110. Saini A, Mahajan S, Ahuja N, Bhagyaraj E, Kalra R, Gupta P. An Accord of Nuclear Receptor Expression in M. Tuberculosis Infected Macrophages and Dendritic Cells. Sci Rep (2018) 8:2296. doi: 10.1038/s41598-018-20769-4 
111. Bhagyaraj E, Tiwari D, Ahuja N, Nanduri R, Saini A, Kalra R, et al. A human xenobiotic nuclear receptor contributes to nonresponsiveness of Mycobacterium tuberculosis to the antituberculosis drug rifampicin. J Biol Chem (2018) 293:3747-57. doi: 10.1074/jbc.M117.818377

112. Guirado E, Rajaram MV, Chawla A, Daigle J, La Perle KM, Arnett E, et al. Deletion of PPAR $\gamma$ in lung macrophages provides an immunoprotective response against M. tuberculosis infection in mice. Tuberc Edinb Scotl (2018) 111:170-7. doi: 10.1016/j.tube.2018.06.012

113. Liu PT, Stenger S, Li H, Wenzel L, Tan BH, Krutzik SR, et al. Toll-Like Receptor Triggering of a Vitamin D-Mediated Human Antimicrobial Response. Science (2006) 311:1770-3. doi: 10.1126/science.1123933

114. Chandra V, Mahajan S, Saini A, Dkhar HK, Nanduri R, Raj EB, et al. Human IL10 repression by Reverb alpha ameliorates Mycobacterium tuberculosis clearance. J Biol Chem (2013) 288:10692-702. doi: 10.1074/jbc.M113.455915

115. Korf H, Vander Beken S, Romano M, Steffensen KR, Stijlemans B, Gustafsson $\mathrm{J}-\AA \AA$, et al. Liver $\mathrm{X}$ receptors contribute to the protective immune response against Mycobacterium tuberculosis in mice. J Clin Invest (2009) 119:1626-37. doi: 10.1172/JCI35288

116. Zhang Y, Zhu H, Yang X, Guo S, Liang Q, Lu Y, et al. Serum vitamin D level and vitamin $\mathrm{D}$ receptor genotypes may be associated with tuberculosis clinical characteristics: A case-control study. Med (Baltimore) (2018) 97: e11732. doi: 10.1097/MD.0000000000011732

117. Roodgar M, Ross CT, Tarara R, Lowenstine L, Dandekar S, Smith DG. Gene expression and TB pathogenesis in rhesus macaques: TR4, CD40, CD40L, FAS (CD95), and TNF are host genetic markers in peripheral blood mononuclear cells that are associated with severity of TB lesions. Infect Genet Evol (2015) 36:396-409. doi: 10.1016/j.meegid.2015.10.010

118. Bertolin K, Gossen J, Schoonjans K, Murphy B. The Orphan Nuclear Receptor Nr5a2 Is Essential for Luteinization in the Female Mouse Ovary. Endocrinology (2014) 155:1931-43. doi: 10.1210/en.2013-1765

119. Vasquez YM, DeMayo FJ. Role of nuclear receptors in blastocyst implantation. Semin Cell Dev Biol (2013) 24:724-35. doi: 10.1016/ j.semcdb.2013.08.004

120. Duggavathi R, Volle DH, Mataki C, Antal MC, Messaddeq N, Auwerx J, et al. Liver receptor homolog 1 is essential for ovulation. Genes Dev (2008) 22:1871-6. doi: 10.1101/gad.472008

121. Kam RKT, Deng Y, Chen Y, Zhao H. Retinoic acid synthesis and functions in early embryonic development. Cell Biosci (2012) 2:11. doi: 10.1186/20453701-2-11

122. Pereira FA, Qiu Y, Zhou G, Tsai MJ, Tsai SY. The orphan nuclear receptor COUP-TFII is required for angiogenesis and heart development. Genes Dev (1999) 13:1037-49. doi: 10.1101/gad.13.8.1037

123. Petit FG, Jamin SP, Kurihara I, Behringer RR, DeMayo FJ, Tsai M-J, et al. Deletion of the orphan nuclear receptor COUP-TFII in uterus leads to placental deficiency. Proc Natl Acad Sci USA (2007) 104:6293-8. doi: 10.1073/pnas.0702039104

124. Jeyasuria P, Ikeda Y, Jamin SP, Zhao L, de Rooij DG, Themmen APN, et al. Cell-Specific Knockout of Steroidogenic Factor 1 Reveals Its Essential Roles in Gonadal Function. Mol Endocrinol (2004) 18:1610-9. doi: 10.1210/ me.2003-0404

125. Pelusi C, Ikeda Y, Zubair M, Parker KL. Impaired Follicle Development and Infertility in Female Mice Lacking Steroidogenic Factor 1 in Ovarian Granulosa Cells. Biol Reprod (2008) 79:1074-83. doi: 10.1095/ biolreprod.108.069435

126. Cloke B, Christian M. The role of androgens and the androgen receptor in cycling endometrium. Endocrinol Uterus Uterine-Relat Disord (2012) 358:166-75. doi: 10.1016/j.mce.2011.06.031

127. Lobaccaro JMA, Gallot D, Lumbroso S, Mouzat K. Liver X Receptors and female reproduction: When cholesterol meets fertility! J Endocrinol Invest (2013) 36:55-60. doi: 10.3275/8765

128. Shahbazi M, Jeddi-Tehrani M, Zareie M, Salek-Moghaddam A, Akhondi MM, Bahmanpoor M, et al. Expression profiling of vitamin D receptor in placenta, decidua and ovary of pregnant mice. Placenta (2011) 32:657-64. doi: 10.1016/j.placenta.2011.06.013

129. Irani M, Merhi Z. Role of vitamin D in ovarian physiology and its implication in reproduction: a systematic review. Fertil Steril (2014) 102:460-8. doi: 10.1016/j.fertnstert.2014.04.046
130. Wei S-Q, Audibert F, Luo Z-C, Nuyt AM, Masse B, Julien P, et al. Maternal plasma 25-hydroxyvitamin D levels, angiogenic factors, and preeclampsia. Am J Obstet Gynecol (2013) 208:390.e1-6. doi: 10.1016/j.ajog.2013.03.025

131. Wei S-Q, Qi H-P, Luo Z-C, Fraser WD. Maternal vitamin D status and adverse pregnancy outcomes: a systematic review and meta-analysis. $J$ Matern-Fetal Neonatal Med Off J Eur Assoc Perinat Med Fed Asia Ocean Perinat Soc Int Soc Perinat Obstet (2013) 26:889-899. doi: 10.3109/ 14767058.2013.765849

132. Wetendorf M, DeMayo FJ. The progesterone receptor regulates implantation, decidualization, and glandular development via a complex paracrine signaling network. Mol Cell Endocrinol (2012) 357:108-18. doi: 10.1016/j.mce.2011.10.028

133. Hapangama DK, Kamal AM, Bulmer JN. Estrogen receptor $\beta$ : the guardian of the endometrium. Hum Reprod Update (2014) 21:174-93. doi: 10.1093/ humupd/dmu053

134. Schaiff WT, Barak Y, Sadovsky Y. The pleiotropic function of PPAR $y$ in the placenta. Mol Cell Endocrinol (2006) 249:10-5. doi: 10.1016/j.mce.2006.02.009

135. Yessoufou A, Hichami A, Besnard P, Moutairou K, Khan NA. Peroxisome Proliferator-Activated Receptor $\alpha$ Deficiency Increases the Risk of Maternal Abortion and Neonatal Mortality in Murine Pregnancy with or without Diabetes Mellitus: Modulation of T Cell Differentiation. Endocrinology (2006) 147:4410-8. doi: 10.1210/en.2006-0067

136. Komar CM. Peroxisome proliferator-activated receptors (PPARs) and ovarian function-implications for regulating steroidogenesis, differentiation, and tissue remodeling. Reprod Biol Endocrinol RBE (2005) 3:41. doi: 10.1186/1477-7827-3-41

137. Goldstein CA, Smith YR. Sleep, Circadian Rhythms, and Fertility. Curr Sleep Med Rep (2016) 2:206-17. doi: 10.1007/s40675-016-0057-9

138. Bugge A, Feng D, Everett LJ, Briggs ER, Mullican SE, Wang F, et al. Rev-erb $\alpha$ and Rev-erb $\beta$ coordinately protect the circadian clock and normal metabolic function. Genes Dev (2012) 26:657-67. doi: 10.1101/gad.186858.112

139. Chute JP, Ross JR, McDonnell DP. Minireview: Nuclear receptors, hematopoiesis, and stem cells. Mol Endocrinol Baltim Md (2010) 24:1-10. doi: 10.1210/me.2009-0332

140. Purton L, Bernstein I, Collins S. All-trans retinoic acid enhances the longterm repopulating activity of cultured hematopoietic stem cells. Blood (2000) 95:470-7. doi: 10.1182/blood.V95.2.470

141. Mullen EM, Gu P, Cooney AJ. Nuclear Receptors in Regulation of Mouse ES Cell Pluripotency and Differentiation. PPAR Res (2007) 2007:61563. doi: $10.1155 / 2007 / 61563$

142. Mullican SE, Zhang S, Konopleva M, Ruvolo V, Andreeff M, Milbrandt J, et al. Abrogation of nuclear receptors $\mathrm{Nr} 4 \mathrm{a} 3$ andNr4a1 leads to development of acute myeloid leukemia. Nat Med (2007) 13:730-5. doi: 10.1038/nm1579

143. Han SJ, O'Malley BW. The dynamics of nuclear receptors and nuclear receptor coregulators in the pathogenesis of endometriosis. Hum Reprod Update (2014) 20:467-84. doi: 10.1093/humupd/dmu002

144. Lebovic DI, Kavoussi SK, Lee J, Banu SK, Arosh JA. PPAR $\gamma$ Activation Inhibits Growth and Survival of Human Endometriotic Cells by Suppressing Estrogen Biosynthesis and PGE2 Signaling. Endocrinology (2013) 154:480313. doi: 10.1210/en.2013-1168

145. Pellegrini C, Gori I, Achtari C, Hornung D, Chardonnens E, Wunder D, et al. The expression of estrogen receptors as well as GREB1, c-MYC, and cyclin D1, estrogen-regulated genes implicated in proliferation, is increased in peritoneal endometriosis. Fertil Steril (2012) 98:1200-8. doi: 10.1016/j.fertnstert.2012.06.056

146. Bulun SE, Cheng Y-H, Yin P, Imir G, Utsunomiya H, Attar E, et al. Progesterone resistance in endometriosis: Link to failure to metabolize estradiol. Int Workshop 11beta 17beta-Hydroxysteroid Dehydrogenases (2006) 248:94-103. doi: 10.1016/j.mce.2005.11.041

147. Bielecki B, Mattern C, Ghoumari AM, Javaid S, Smietanka K, Abi Ghanem C, et al. Unexpected central role of the androgen receptor in the spontaneous regeneration of myelin. Proc Natl Acad Sci (2016) 113:14829-34. doi: $10.1073 /$ pnas.1614826113

148. Chen W-D, Wang Y-D, Zhang L, Shiah S, Wang M, Yang F, et al. Farnesoid $\mathrm{X}$ receptor alleviates age-related proliferation defects in regenerating mouse livers by activating forkhead box mlb transcription. Hepatology (2010) 51:953-62. doi: 10.1002/hep.23390 
149. Dierickx P, Van Laake LW, Geijsen N. Circadian clocks: from stem cells to tissue homeostasis and regeneration. EMBO Rep (2018) 19:18-28. doi: 10.15252/embr.201745130

150. Huang W, Ma K, Zhang J, Qatanani M, Cuvillier J, Liu J, et al. Nuclear Receptor-Dependent Bile Acid Signaling Is Required for Normal Liver Regeneration. Science (2006) 312:233-6. doi: 10.1126/science.1121435

151. Pantos C, Mourouzis I. Thyroid hormone receptor $\alpha 1$ as a novel therapeutic target for tissue repair. Ann Transl Med (2018) 6:254. doi: 10.21037/ atm.2018.06.12

152. Tschuor C, Kachaylo E, Limani P, Raptis DA, Linecker M, Tian Y, et al. Constitutive androstane receptor (Car)-driven regeneration protects liver from failure following tissue loss. J Hepatol (2016) 65:66-74. doi: 10.1016/ j.jhep.2016.02.040

153. Pestka A, Toth B, Kuhn C, Hofmann S, Wiest I, Wypior G, et al. Retinoid X receptor $\alpha$ and retinoids are key regulators in apoptosis of trophoblasts of patients with recurrent miscarriages. J Mol Endocrinol (2011) 47:145-156. doi: 10.1530/jme-11-0002

154. Toth B, Bastug M, Scholz C, Arck P, Schulze S, Kunze S, et al. Leptin and peroxisome proliferator-activated receptors: impact on normal and disturbed first trimester human pregnancy. Histol Histopathol (2008) 23:1465-75. doi: 10.14670/hh-23.1465

155. Rose Ukibe N, Ukibe S, Ikechukwu Onwubuya E, Onyenekwe C, Nwamaka Monago I, Emelumadu O, et al. Possible impact of variations in some Cytokine levels during menstrual cycle in women of reproductive age infected with Pulmonary Tuberculosis at Nnewi, Nigeria. Clin Invest (2018) 08:63-73. doi: 10.4172/Clinical-Investigation.1000130

156. Datta A, Chaudhuri A, Chatterjee S, Chowdhury R, Bhattacharya B. Role of endometrial cytokines of the female genital tract tuberculosis in the context of infertility. BLDE Univ J Health Sci (2018) 3:24-30. doi: 10.4103/ bjhs.bjhs_1_18

157. Chaouat G, Menu E, Clark DA, Dy M, Minkowski M, Wegmann TG. Control of fetal survival in CBA $\times$ DBA/2 mice by lymphokine therapy. J Reprod Fertil (1990) 89:447-58. doi: 10.1530/jrf.0.0890447

158. Tezabwala BU, Johnson PM, Rees RC. Inhibition of pregnancy viability in mice following IL-2 administration. Immunology (1989) 67:115-9.

159. Fakih H, Baggett B, Holtz G, Tsang K-Y, Lee JC, Williamson HO. Interleukin-1: a possible role in the infertility associated with endometriosis. Fertil Steril (1987) 47:213-7. doi: 10.1016/S0015-0282(16) 49993-0

160. Lebovic DI, Bentzien F, Chao VA, Garrett EN, Meng YG, Taylor RN. Induction of an angiogenic phenotype in endometriotic stromal cell cultures by interleukin-1 $\beta$. Mol Hum Reprod (2000) 6:269-75. doi: $10.1093 / \mathrm{molehr} / 6.3 .269$

161. Straus DS, Glass CK. Anti-inflammatory actions of PPAR ligands: new insights on cellular and molecular mechanisms. Trends Immunol (2007) 28:551-8. doi: 10.1016/j.it.2007.09.003

162. Pourcet B, Gage MC, León TE, Waddington KE, Pello OM, Steffensen KR, et al. The nuclear receptor LXR modulates interleukin-18 levels in macrophages through multiple mechanisms. Sci Rep (2016) 6:25481. doi: $10.1038 /$ srep 25481

163. Lo Verme J, Fu J, Astarita G, La Rana G, Russo R, Calignano A, et al. The Nuclear Receptor Peroxisome Proliferator-Activated Receptor- $\alpha$ Mediates the Anti-Inflammatory Actions of Palmitoylethanolamide. Mol Pharmacol (2005) 67:15-19. doi: 10.1124/mol.104.006353

164. Sun M, Cui W, Woody SK, Staudinger JL. Pregnane X Receptor Modulates the Inflammatory Response in Primary Cultures of Hepatocytes. Drug Metab Dispos (2015) 43:335-43. doi: 10.1124/dmd.114.062307
165. Hollman DAA, Milona A, van Erpecum KJ, van Mil SWC. Antiinflammatory and metabolic actions of FXR: Insights into molecular mechanisms. Biochim Biophys Acta BBA - Mol Cell Biol Lipids (2012) 1821:1443-52. doi: 10.1016/j.bbalip.2012.07.004

166. Nejati Moharrami N, Bjørkøy Tande E, Ryan L, Espevik T, Boyartchuk V. ROR $\alpha$ controls inflammatory state of human macrophages. PloS One (2018) 13:e0207374. doi: 10.1371/journal.pone.0207374

167. Maijenburg MW, Gilissen C, Melief SM, Kleijer M, Weijer K, Ten Brinke A, et al. Nuclear receptors Nur77 and Nurr1 modulate mesenchymal stromal cell migration. Stem Cells Dev (2012) 21:228-38. doi: 10.1089/scd.2011.0076

168. Knabl J, Pestka A, Hüttenbrenner R, Plösch T, Ensenauer R, Welbergen L, et al. The liver $\mathrm{x}$ receptor in correlation with other nuclear receptors in spontaneous and recurrent abortions. PPAR Res (2013) 2013:575604. doi: 10.1155/2013/575604

169. Bełtowski J, Semczuk A. Liver X receptor (LXR) and the reproductive system - a potential novel target for therapeutic intervention. Pharmacol Rep (2010) 62:15-27. doi: 10.1016/S1734-1140(10)70239-5

170. Banerjee P, Ghosh S, Dutta M, Subramani E, Khalpada J, Roychoudhury S, et al. Identification of key contributory factors responsible for vascular dysfunction in idiopathic recurrent spontaneous miscarriage. PloS One (2013) 8:e80940. doi: 10.1371/journal.pone.0080940

171. Piltonen TT. Polycystic ovary syndrome: Endometrial markers. Best Pract Res Clin Obstet Gynaecol (2016) 37:66-79. doi: 10.1016/j.bpobgyn. 2016.03.008

172. Achache H, Revel A. Endometrial receptivity markers, the journey to successful embryo implantation. Hum Reprod Update (2006) 12:731-46. doi: 10.1093/humupd/dml004

173. Lessey BA, Castelbaum AJ, Sawin SW, Sun J. Integrins as markers of uterine receptivity in women with primary unexplained infertility. Fertil Steril (1995) 63:535-42. doi: 10.1016/S0015-0282(16)57422-6

174. Wetendorf M, DeMayo FJ. Progesterone receptor signaling in the initiation of pregnancy and preservation of a healthy uterus. Int J Dev Biol (2014) 58:95-106. doi: 10.1387/ijdb.140069mw

175. Stephanou A, Ross R, Handwerger S. Regulation of human placental lactogen expression by 1,25-dihydroxyvitamin D3. Endocrinology (1994) 135:2651-6. doi: 10.1210/endo.135.6.7988455

176. Shin JS, Choi MY, Longtine MS, Nelson DM. Vitamin D effects on pregnancy and the placenta. Placenta (2010) 31:1027-34. doi: 10.1016/j.placenta.2010.08.015

177. Murthi P, Yong HEJ, Ngyuen TPH, Ellery S, Singh H, Rahman R, et al. Role of the Placental Vitamin D Receptor in Modulating Feto-Placental Growth in Fetal Growth Restriction and Preeclampsia-Affected Pregnancies. Front Physiol (2016) 7:43. doi: 10.3389/fphys.2016.00043

178. Barrera D, Avila E, Hernández G, Méndez I, González L, Halhali A, et al. Calcitriol affects hCG gene transcription in cultured human syncytiotrophoblasts. Reprod Biol Endocrinol RBE (2008) 6:3. doi: 10.1186/ 1477-7827-6-3

Conflict of Interest: The authors declare that the research was conducted in the absence of any commercial or financial relationships that could be construed as a potential conflict of interest.

Copyright (c) 2020 Gupta and Gupta. This is an open-access article distributed under the terms of the Creative Commons Attribution License (CC BY). The use, distribution or reproduction in other forums is permitted, provided the original author(s) and the copyright owner(s) are credited and that the original publication in this journal is cited, in accordance with accepted academic practice. No use, distribution or reproduction is permitted which does not comply with these terms. 